\section{LIMITAÇÃO DA RESPONSABILIDADE DO COMERCIANTE INDIVIDUAL}

\section{Antônio Martins Filho}

Professor Catedrático de Direito Comercial da Facul-

dade de Direito do Ceará, Catedrático de Econom
Política da Faculdade de Ciências Economicas.

\section{T E S E}

A emprêsa individual de responsabilidade limitada, constituindo a última fase do processo evolutivo da limitação dos riscos, é insistentemente reclamada pelos ágentes da atividade econômica dos novos tempos.

Recusando-a de direito, não evitará o legislador a existência de fato dêsse tipo de emprêsa, que passa a funcionar sob forma de sociedade fictícia ou unipessoal.

Dada a importância e complexidade de que o instituto se reeste - e atendendo a que se trata de problema de ordem técnica - impõe-se o seu estudo e discussão em maior amplitude, para que se fecida sôbre a conveniência ou inoportunidade de sua inclusão no novo Código Mercantil.

\section{I S C U S S Ã O}

\section{I - CONSIDERAÇõES PRELIMINARES}

a) Nova codificação do Direito Comercial

1 - A conveniência de uma revisão periódica dos códigos constitui matéria que, pela sua próprio natureza, não pode comportar contestação. Decorre da circunstância de que as leis, tal qual os indivíduos a que se destinam servir, sofrem também a ação incoercível do tempo. E desde que lhes falta o atributo da imutabilidade, terão necessàriamente de se ajustar aos novos imperativos sociais, resultantes da lei da evolução.
2 - Essa a situação em que ora se encontra o Código Comercial brasileiro.

Promulgado em 1850, quando a atividade mercantil estava imensamente distanciada do gráu de intensidade que hoje a caracteriza, é natural que o secular Estatuto não mais satisfaça às exigências dos dias presentes.

Falhas e lacunas se foram tornando evidentes, sendo em parte remediadas com o aparecimento de leis novas, algumas sucessivamente modificadas. Ëm conseqüência disso, as linhas estruturais do velho Código, perdendo a sua feição primitiva, apresentam, hoje, profundas e justificáveis mutilações.

Com efeito, o século que lhe assinala a eficácia foi precisamente aquêle em que se fizeram sentir, de maneira a mais decisiva, a influência da máquina no âmbito dos negócios, o aperfeiçoamento e especialização da técnica, a hegemonia do crédito em relação à economia monetária, o advento da aeronavegação, isto é, o aparecimento de um mundo novo, dinâmico, e complexo para as atividades industrial e mercantil.

3 - Ressaltando, embora, a necessidade de uma nova codificação do nosso Direito Comercial, contudo é mister frisar que não se trata de tarefa fácil ou de simples concretização.

Comprova a veracidade dessa afirmativa a circunstância de já se haver iniciado algumas tentativas neste sentido, a começar pelo Projeto Inglês de Souza, que data de 1912.

Preconizando a unificação do direito privado - idéia que posteriormente perdeu a sua intensidade, em virtude da promulgação do Código Civil - o projeto do insigne comercialista ainda conseguiu subir ao Senado, sendo ali confiado ao estudo de uma Comissão Especial.

A abundância de emendas e correções, a par do expurgo de tôda a matéria de direito civil, desvirtuaram a tentativa de codificação de Inglês de Sousa, daí se originando o chamado Projeto do Senado, remetido à Câmara dos Deputados, em 1927.

Dois anos depois, eis que surge o Substitutivo do Desembargador Vieira Ferreira, o qual, apesar de oferecer algumas melhorias em relação aos trabalhos até então realizados, ainda não logrou solucionar o problema em equação.

4 - No período de restrições constitucionais, que vai de 1930 até 1945 - com ligeiro interregno resultante da Constituição de 1934 - nada ou quase nada se conseguiu efetivar em favor do novo Código, se bem que se tratasse de uma época sobremodo propícia à elaboração de um trabalho dêsse gênero.

5 - Reconstitucionalizado o país e ocorrendo a circunstância favorável de se encontrar como detentor da Pasta da Justiça um 19 - R. D. $10^{\circ}$ Vol. 
professor de Direito Comercial, seria de esperar que o assunto retornasse à ordem do dia, o que efetivamente aconteceu.

$\mathrm{Na}$ verdade, a uma Comissão de eméritos juristas foi confiada a incumbência da formulação do anteprojeto do novo Código.

Mais ainda: preocupado em levar avante a idéia que esposou, o Senhor Ministro Adroaldo Mesquita da Costa houve por bem confiar ao Desembargador Florêncio de Abreu a tarefa de apresentar um "Esbôço" que, servindo de ponto de partida às discussões, viesse facilitar o trabalho da egrégia Comissão.

6 - E' bem de ver que tais antecedentes, aqui sumàriamente focalizados, terão o mérito de realçar a magnitude e alta significação. do Congresso Jurídico comemorativo do cinqüentenário de fundação da Faculdade de Direito da Universidade do Rio Grande do Sul, cujor temário preferencial é totalmente reservado ao estudo do nosso $\mathrm{Di}_{\mathrm{i}}$ reito Mercantil.

\section{b) "Esbôço" Florêncio de Abréu}

7 - Preliminarmente, cumprimos o dever de aplaudir e de felicitar ao Senhor Desembargador Florêncio de Abreu, pela valiosa cooperação patriòticamente prestada à feitura do anteprojeto do novo Código.

Atendendo, porém, a que se trata de "matéria plástica", segundo afirma o seu autor, permitimo-nos a liberdade de apreciar alguns pontos fundamentais do "Esbôço", aliás, em abono da tese que nos propomos defender.

8 - Acreditamos que um Código, ao contrário de uma simples consolidação, para que possa alcançar a finalidade a que se destina, terá necessàriamente de oferecer soluções racionais e lógicas aos múltiplos e complexos problemas surgidos ou tangenciados pelas exigências da economia contemporânea, que ora se encontra em luta pertinaz pela sobrevivência do sistema capitalista.

Colhêr e sistematizar o que se encontra disperso de jure constituto; recusar de plano a adoção de novos institutos, na pressuposição de problemáticas dificuldades que possam surgir na vida prática; contornar dificuldades ou colocar à margem a solução de situação de fato que estão a exigir a argúcia e percuciência do legislador - parece-nos atitude que se não justifica, se na verdade desejamos um Código que atenda aos imperativos da ordem econômica e que demonstre o nível de evolução doutrinal dos nossos. juristas.

9 - Porque assim pensamos, somos levados a discordar do eminente autor do "Esbốço", quando declara que, a não ser mediante "uma transformação brusca, $a b$ imi fundamentis, no sistema do direito comercial brasileiro, não seria possível confiná-lo na órbita exclusiva das atividades da "emprêsa", com o caráter de direito essencialmente subjetivo" (1).

Em verdade, não seria oportuno e, quiçá, necessário examinarmos mais detidamente a conveniência ou desvantagem dessa considerada "brusca transformação"? Já não a teríamos iniciado cautelosamente, em matéria de direito falencial, quando o legislador acolheu a tese de que a falência da sociedade não acarretará a dos sócios solidários e ilimitadamente responsáveis? Como persistir em confinar a matéria comercial na absoleta teoria do ato de comércio, colocando à margem, sem maior exame, a nova teoria da emprếsa?

Por outro lado, um código comercial moderno - o rumeno já não conseguiu realizar idêntica transformação?

10 - Essas e outras razões, que igualmente fundamentam a nossa orientação doutrinária em matéria de direito mercantil, colocam-nos em posição contrária ao ponto de vista adotado pelo senhor Desembargador Florêncio de Abreu.

Tal divergência mais se acentua quando o eminente autor do "Esbôço" se refere à tendência predominante da limitação dos riscos a que estão expotos os homens de negócio, de que às vêzes resulta a concentração de tôdas as ações de uma sociedade anônima nas mãos de um único titular.

Em sentido oposto a essa tendência, afirma categòricamente o Desembargador Abreu, na parte final da exposição que justifica a sua orientação doutrinária:

"Admitir a lei a sociedade anônima com um só acionista ou a sociedade limitada com um só quotista, a fortiori deveria reconhecer a emprêsa individual de responsabilidade limitada, o que pareceria imprudente, ou inoportuno, pelas graves questões que levantaria na prática, especialmente entre credores da emprêsa e credores particulares do comerciante, pela dificuldade de estabelecer nítida separação de patrimônios. Parece-me que, neste ponto, a lei deve continuar reservada.

O exemplo do Principado de Liechtenstein, ao que me consta, não logrou prosélitos" $\left({ }^{1}\right)$.

1 - Em que pese à autoridade do ilustre mestre, acreditamos não ser difícil justificar teòricamente a necessidade do reconhecimento legal da sociedade anônima de um só acionista.

Trata-se, é certo, de um meio indireto e, pois, anormal da limitação da responsabilidade do comerciante singular, pelo que seria preferível chegar a êsse fim diretamente.

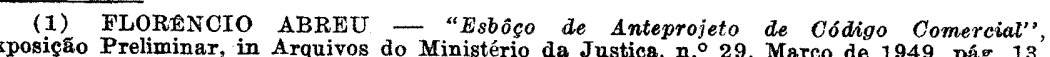

(1) Trabalo cit., pág. 35.
(1) Ministério da Justiga, n. ${ }^{\circ}$ 29, Março de 1949, pág. 13 . 
Mas, de qualquer forma, teremos de admitir que não existem razões jurídicas decisivas contra o reconhecimento da chamada sociedade unipessoal $\left({ }^{2}\right)$.

No mais recente Projeto de Vivante, em cuja doutrina o autor do "Esbôço" em parte se orientou, é amplamente defedido êsse ponto de vista, sendo que o grande mestre italiano preconizou não só o reconkecimento legal da sociedade anônima conduzida à unipessoalidade depois de fundada, como ainda chegou a estabelecer normas para a sua criação (1)

12 - No entanto, para que modificar a fisionomia do instituto da sociedade anônima, que pressupõe um certo estado de fato $\left(^{1}\right)$, emergente da existência de uma coletividade de pessoas, subjacente ao ato de constituição?

Se as injunções de ordem econômica assim o exigem, por que não possibilitar ao comerciante individual o meio direto de limitação dos riscos a que está exposto, na prática mercantil?

Não seria preferível, ou talvez necessária, a instituição da emprêsa individual de responsabilidade limitada, a fim de evitar a generalização das sociedades unipessoais ou fictícias, conforme ocorre na atualidade?

Esta a tese que, a seguir, pretendemos defender.

(2) Cf. ROBERTO GOLDSCHIMIDT - "Problemas Jurídicos de la Sociedad Anonima," Editorial Delpalma, Buenos Aires, 1946, pág. 142.

legal (1.) Vivante pretendeu resolver o problema das sociedades unipessoais no quadro "Art. 1. La societs anonima per azioni puo 6 tes normas:

anche da una sola persona mediante l'assegnazione di un capitale per pubblico di determinati affar

Il capitali dere essere diviso in azioni di uguale ammontare e dev'essere versato

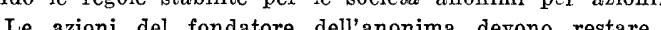

tel fondatore dell'anonima devono restare vincolate per due annil Tale vincolo deve resultare da apposita annotazione nel libro dei soci $e$, in quanto siano emessi, sui titoli.

Lo statuto deve contenere l'indicazione del compenso fisso e della partecipazione agli utili assegnatio all'unico azionista, che puó essere anche l'unico membro

Art. 2. Per l'anonima con una sola persona non é obbligatoria la costituzione
del consiglio. I1 deposito del bilancio dev' essere accompagnato dalla relazione di un revisore dei conti, nella quale dovranno prendersi in speciale considerazione le operazione dell unico azionista e dei membri del comitato e del consiglio con la società Art. 3. Fino a quando le azione siano tutte di proprieta di una sola persona, non é luogo alla convocazione dell'assemblea, ma l'unico azionista deve accompagnare sua qualità.

Art. 4. Qualora le azioni siano ripartite fra piú persone, entra in vigore la
disciplina propria delle anonime per azione". Apud $\mathrm{R}$. Goldschimidt, obr. cit. pags 140 e 141 .

Libraire Gide PAUL CARRY - "La responsabilité limitée du commerçant individuel",

\section{II - PRESSÃO DOS FATOS SÔBRE A LEI}

a) $O$ princípio da limitação da responsabilidade

1 - Um rápido exame da história do comércio, considerado como instituição de caráter profissional, torna evidente a tendência de limitação da responsabilidade, que aliás corresponde a u'a mais equitativa repartição dos riscos entre os agentes da atividade mercantil.

Não nos parece que essa preocupação deva ser considerada injustificável ou imoral. Pelo contrário, deriva da natureza do comércio - o risco - e vai sucessivamente aumentando de intensidade, sob a pressão de circuntâncias inelutáveis.

2 - Por outro lado, a análise ontogênica da noção de responsabilidade, pondo em relêvo as várias facêtas de que ela se reveste, justifica suficientemente aquela tendência ou preocupação.

Com efeito, a responsabilidade civil e a penal originam-se da noção de responsabilidade moral. Mas, enquanto a penal tem o seu fundamento psicológico na responsabilidade moral - que não pode ser limitada - a civil desta se distingue e passa a expressar uma noção técnica, isto é, de divisão equitativa dos riscos.

Dêsse modo, permitir a limitação da responsabilidade contratual em determinados casos, nada mais é do que corrigir a repartição dos riscos, o que representa, afinal de contas, um probletma de ordem técnica ${ }^{1}$ ).

3 - O princípio da limitação da responsabilidade, em matéria de direito comercial, vem passando por fases sucessivas e perfeitamente caracterizáveis.

Tal processo evolutivo, que ora se dirige em direção da emprêsa singular de responsabilidade limitada, encontra a sua explicação em imperativos de ordem sociológica, que nada mais significam do que a revolta dos fatos contra a lei.

4 - A societas do direito romano é apontada como o ponto de partida do princípio da limitação da responsabilidade.

Não se tratava, é certo, de uma sociedade comercial com tôdas as características que hoje a definem, mas, sim, de um contrato em que duas ou mais pessoás deliberavam recìprocamente pôr em comum os seus bens e serviços, com o objetivo de uma utilidade também comum $\left({ }^{1}\right)$.

(1) Cf. ROGER ISCHER - "Vers la responsabilité limitée du commerçant indivi-
duel", Editions SPES S. A., Lausanne, 1939, pág. 7 e segs.

Alves, Rio, 1910, DfLE DE SOUZA - "Direito Comercial" - Preleşöes, ed. Francisco 
5 - Com o desenvolvimento e expansão comercial das cidades da Itália, de que surgiu o chamado direito estatutário, adveio a sociedade com firma ou em nome coletivo e, a seguir, a sociedade comanditária.

A sociedade em nome coletivo, cronològicamente considerada a primeira instituição corporativa do direito mercantil, ainda hoje conserva os seus fundamentos originários: responsabilidade ilimitada e solidariedade dos sócios.

Já aí se evidencia a existência de um patrimônio comercial distinto e que não se confunde com os dos respectivos associados.

Quanto às relações internas da sociedade, são os riscos repartidos entre os seu smembros titulares, em proporção ao gráu de responsabilidade que cada um assume para com a emprêsa.

6 - Com o advento da sociedade comanditária, o princípio da limitação dos riscos passa a assumir feição mais característica, uma vez que atinge as próprias relações externas da organização.

Dada a importância que o novo instituto oferece para as conclusões a que pretendemos chegar, não será incabível remontar às suas origens históricas, se bem que em traços rápidos.

7 - A ânsia de possuir mais é condição inerente à natureza humana. Êsse desejo aumenta ou diminui de intensidade, de acôrdo com as circunstâncias de um dado momento ou em virtude de certos atributos personalíssimos.

8 - As transformações que se foram operando na última fase da idade média determinaram o aparecimento do contrato de pacotilha, que, aliás, reflete as condições peculiares àquela época.

É que, de um lado, os empreendimentos marítimos estavam a reclamar maior soma de capital, a fim de tornar possível transações mais avultadas e, pois, mais lucrativas. De outro lado, necessitavam os nobres de novos proventos materiais que lhes pudessem assegurar a continuação do predomínio na sociedade.

Mas, sendo a mercancia considerada profissão infamante ou menos honrosa e, portanto, incompatível com a dignidade da nobreza, teria de surgir nova espécie de negócio que satisfizesse àquelas necessidades convergentes. Essa modalidade foi encontrada no contrato de pacotilha, pelo qual o capitalista fornecia ao mestre ou capitão de navio determinada soma, sob as seguintes condições: a) o nome do prestamista não ficaria ostensivamente ligado à transação; b) os lucros seriam repartidos na proporção convencionada; c) na hipótese de malôgro ou prejuízo, a responsabilidade do dador se limitaria ao valor da importância então fornecida.

Nesses elementos constitutivos do contrato de pacotilha tem a sociedade em comandita dos nossos dias os seus traços estruturais: solidariedade e responsabilidade ilimitada para o sócio ostensivo ou comanditado; limitação de responsabilidade para o sócio oculto ou comanditário.

8 - As grandes transformações que assinalam o início da era moderna, determinando o desenvolvimento intensivo das atividades de ordem econômica, teriam forçosamente de reclamar um novo tipo de sociedade capaz de atender ao vulto sempre crescente das operações. Eis que surge, tangenciada por tais exigências, a sociedade anônima, cujo aparecimento constitui mais um elo da cadeia evolutiva da limitação dos riscos.

$\mathrm{Na}$ verdade, o novo instituto jurídico, que teve a sua origem no século XVII, mas que tomou o maior incremento no século XIX, possibilitou a limitação da responsabilidade a todos os seus componestes ou acionistas e não apenas a determinada categoria de sócios, conforme se verifica em relação à sociedade comanditária.

9 - Mas, pela sua própria natureza e origem, a soceidade anônima é destinada aos empreendimentos de grande vulto, pelo que às vêzes reclama, para que possa alcançar o seu objetivo, verdadeira coletividade de co-participantes.

Destiná-la à exploração de negócios de pouco vulto seria desvirtuar a sua verdadeira finalidade.

Êsses e outros motivos, também ponderáveis, fizeram surgir novo instituto jurídico, hoje grandemente generalizado e que entre nós se denomina - sociedade por quotas de responsabilidade limitada.

Já aqui o benefício da limitação dos riscos poderá ser fruído apenas por duas pessoas. Estas, porém, ao contrário do que ocorre na sociedade anônima, são solidárias e responsáveis até ao limite do capital societário.

10 - Desenvolvendo outra ordem de considerações, por igual relacionadas com o princípio da limitação da responsabilidade, é bem de ver que, primitivamente, respondia o devedor pelo inadimplemento da dívida, com o corpo, a honra, a liberdade e até com o próprio cadáver.

Esses crudelíssimos costumes perduraram durante muito tempo, ora mais ora menos acentuados. E mesmo na vigência da $L$ ex Duodecin Tabularum ainda se fizeram sentir com "a odiosa medida da manus injectio contra o confessus e o judicatus, permitindo ao credor conservar o devedor in carcere privato, vendê-lo como escravo trans Tiberim e até matá-lo e in partes secare" ${ }^{1}$ ).

(1) CARVALHo DE MENDONCA, J. X. - "Tratado de Direito Commereial
Brasileiro", vol. VII, pág. 14, in nota. 
Depois, com o advento do direito pretoriano, sensível modificação operou-se relativamente ao devedor em mora, pois, sendo admitida a execução real, a responsabilidade pela dívida contraída deixou de encerrar um vínculo exclusivamente pessoal e passou a ser considerada uma relação de ordem patrimonial $\left({ }^{2}\right)$.

Já então não mais a pessoa física do devedor, porém os seus bens, passam a representar a garantia comum dos seus credores.

De início, a totalidade dos bens. Depois, apenas uma parte dêles... desde que o devedor exerça a mercancia por meio de determinadas formas societárias.

A essa altura, parece oportuno inquirir:

- Se duas pessoas associadas podem limitar a responsabilidade, por que isoladamente lhes é vedado fazê-lo? Não é verdade que a limitação dos riscos, em matéria de direito civil, constitui problema de ordem técnica e, pois, capaz de ser solucionado pelo acolhimento de novo instituto jurídico?

Noutras palavras: como explicar o estacionamento do processo evolutivo da limitação da responsabilidade na emprêsa comercial societária, quando é evidente que a última etapa dessa evolução está na emprêsa do comerciante individual?

- O tradicional argumento da "indivisibilidade do patrimônio" e outros que tais, poderão ser invocados, à guisa de resposta a essas interrogações. Mas, a êles teremos ensêjo de abordar, em outro capítulo dêste trabalho.

Por enquanto limitamo-nos a reconhecer que a emprêsa individual de responsabilidade limitada representa um imperativo da hora presente, isto é, mais uma pressão dos fatos sôbre a lei.

b) Sociedades unipessoais e fictícias

1 - E' fora de dúvida que o pensamento do legislador, incorporando ao direito positivo o instituto da sociedade anônima, foi o de atender a uma determinante social específica ou seja - possibilitar a concentração de avultada soma de capital, indispensável à realização de gigantescos empreendimentos que, pela sua própria natureza, exigem a co-participação de muitos.

Parece também indubitável que êsse pensamento vem sendo freqüentemente desvirtuado na prática mercantil, já pelo uso do instituto na exploração de negócios de pouco vulto, já pela sua utilização para o desfruto de um único indivíduo.

(2) Cf. MARTTNS FILHO - "Da liquidez do título de crédito na íalência".
Poder-se-á dizer que o pensamento do legislador não deverá prevalecer diante da realidade dos fatos e também que não é estranhável ou raro a aplicação de uma determinada norma jurídica para a consecução de um fim indireto $\left(^{1}\right)$.

Mas, essas razões não justificam a existência da sociedade unipessoal. Pois, - como acentua Paul Carry, - se observamos que tôda a organização dêsse instituto (sociedade anônima) tal qual a fixou o legislador, repousa sôbre certos dados da experiência; se constatamos que a forma adotada pela lei supõe um certo estado de fato eque a adoção dessa forma, para fins imprevistos, cria uma discordância evidente entre a aplicação prática e a organização legislativa temos então o direito de dizer que há um fenômeno anormal e que êste revela, sem dúvida possivel, uma lacuna ( $\left.{ }^{1}\right)$.

2 - Ademais, a significação conceitual de sociedade implica intrìnsecamente a existência de duas ou mais pessoas, que recìprocamente convencionam a conjugação de esforços e de recursos para alcançarem um fim comum.

Considerada a questão sob êste aspecto, não há como justificar a existência da sociedade unipessoal.

3 - No entanto, êsse fenômeno é fàcilmente verificável, a igual do das sociedades fictícias, que ora campeiam com mais abundância no âmbito das sociedades por quotas de responsabilidade limitada.

O problema, aliás, se reveste de maior complexidade pelo fato de tais sociedades não resultarem, em tôdas as hipóteses, da execução de um plano pré-estabelecido.

Com efeito, circunstâncias supervenientes ao ato de constituição podem determinar que tôdas as ações de uma sociedade anônima - ou tôdas as quotas de uma sociedade limitada - sejam concentradas nas mãos de um único titular.

3 - Não nos move a intenção de aprofundar o assunto, o que aliás seria impraticável, nos estreitos limites desta tese.

Contudo, parece-nos indispensável definir mais nìtidamente o nosso pensamento, quer em relação ao que se entende por "sociedades. fictícias", quer a propósito das chamadas "sociedades unipessoais".

4 - Nas oscilações da vida econômica hodierna, não raro acontece o fato do comerciante singular pretender beneficiar-se com a limitação dos riscos a que se expõe na prática mercantil.

Para conseguir essa finalidade, delibera organizar uma socieda(1) Vide TULLIO ASCARELLLI - O negócio indireto, in "Problemas das Sociedades.
Anônimas e Direito Comparado", edição Saraiva, S. Paulo, 1945, pág. 101 e segs. (1) PAUL CARRY - "La responsabilité limitée du commerçant individuel", Ge-
néve, 1928, pág. 20 . 
de anônima, com o concurso de outras pessoas estranhas ao giro especulativo e que, a título de favor, concordam em figurar no ato de constituição, a fim de tornar possível o funcionamento do ente societário.

Posteriormente, ainda se prontificam a assinar os livros de ata ou até mesmo a comparecer às assembléias convocadas. Tudo ficará aprovado sumàriamente e a organização vai realizando o seu objetivo, acobertada por uma aparente legalidade.

Pode ainda, o comerciante individual, recorrer ao tipo - sociedade por quotas de responsabilidade limitada - hipótese que se torna mais freqüente, pelo menor número de formalidades a preencher. Desde que o capital seja logo integralizado, passam-se as ressalvas e a emprêsa se movịmenta...

Aí, pois, o que se entende por sociedades fíctícias, isto é, originàriamente organizadas em função do interêsse de uma pessoa individual.

5 - A freqüuência de tal fenômeno na vida prática, e a sua intensidade nos últimos tempos, levam os doutrinadores ao estudo de uma interpretação mais aprofundada dos princípios jurídicos, no sentido de saber se as sociedades fictícias podem ou devem ser reconhecidas, mesmo independente de reforma legislativa.

$O$ problema é de molde a suscitar as seguintes perquirições:

- Até a que ponto deve prevalecer o princípio da autonomia da vontade? Qual o conteúdo dêsse princípio em face à sociedade que surge e que vive em função de uma aparente legalidade? Deve a vontade declarada no ato de constituição prevalecer sôbre a vontade real? Trata-se da hipótese simulação? Pode êsse vício ser argüido, mesmo na ausência do animus fraudandi?

Em substancioso trabalho de doutrina recentemente publicado o emérito jurista português Arruda Correia põe em equação os vários problemas relacionados com as sociedades dessa espécie e conclui assim:

"Efetivamente, a sociedade que temos chamado de fictícia representa um desvio da forma jurídica do contrato de sociedade mercantil da sua função típica. Êsse desvio poderá não determinar a nulidade do contrato: logo veremos isso. Mas naturalmente só o não determinará enquanto o fim atípico visado pelos contraentes fôr em si mesmo lícito e puder ser reconhecido. Havendo fraude direta à lei, ou representando simplesmente a celebração do contrato o processo escolhido para se causar a terceiro um prejuízo econômico, deixará de não existir obstáculo ao reconhecimento como sociedade do que nada mais tem, da verdadeira sociedade, além do nome e a forma" ( $\left.{ }^{1}\right)$. (1) ANTONIO DE ARRUDA FERRER CORREIA
pnipessoais", Liv, Atlântica, Coimbra -1948 , págs. 190 e 191.
6 - Outro, porém, é o problema da sociedade unipessoal, isto é, aquela em que a vontade declarada no ato de constituição corresponde exatamente à vontade real dos associados.

Aqui, com efeito, a intenção dos fundadores do ente societário foi a de conjugar recursos materiais e esforços para o fim de explorar um negócio dado, cujos proventos serão repartidos proporcionalmente em relação ao número de quotas ou ações que cada um subscreveu para a formação do capital. Visa-se, a par do escopo de lucro, a limitação da responsabilidade $e$, pois, dos riscos inerentes à exploração do negócio.

E' de notar que, originàriamente, a entidade se formou de modo normal, com referência à pluralidade de associados que a lei exige, de acôrdo com o tipo societário adotado.

Depois, eis que a pluralidade desaparece e o ente social é levado à unipessoalidade, por vários motivos supervenientes que conduzem ao mesmo fim.

A essa altura, deparam-se-nos novos problemas de interpretação, aliás distintos da hipótese da sociedade fictícia, na forma anteriormente delineada.

- Será posșível admitir, de jure constituto, a sociedade unipessoal? Sociedade de uma só pessoa não constitui alguma coisa de paradoxal ou lògicamente inconcebível? $\mathrm{O}$ princípio $\mathrm{da}$ autonomia do patrimônio afetado à emprêsa não justificará, porventura, a permanência da personalidade jurídica $e$, pois, a existência de direito da sociedade reduzida a um único titular? Qual a condição e a natureza jurídica da sociedade unipessoal?

Tais indagações emanam da natureza do fenômeno a que ora nos reportamos, mas a sua análise excede os estreitos limites dêste trabalho.

7 - Apesar disso, parece-nos oportuno salientar que, de um certo modo, a lei brasileira disciplinadora do instituto da sociedade anônima admite a possibilidade da existência da sociedade unipessoal.

Ali, com efeito, entre os vários motivos determinantes da dissolução da sociedade, figura o da redução do número de acionistas a menos de sete, desde que êsse minimo não seja preenchido até a seguinte assembléia geral ordinária $\left({ }^{2}\right)$.

Ora, se o texto legal se refere a uma redução a "menos de sete" e não fixa o mínimo, implìcitamente admite a possibilidade de concentração de tôdas as ações nas mãos de um único acionista. E desde que a dissolução só ocorrerá na hipótese daquele número não ser

(1) Decreto-Lei N. 2.627, de 26 de Setembro de 1940, Art. 137, alínea 
restabelecido até a próxima assembléia ordinária, logo se reconhece de direito a existência da sociedade unipessoal.

8 - Em comentários a êsse dispositivo, Trajano de Miranda Valverde esposa a tese segundo a qual "os atos e operações praticados, em nome da sociedade, pelos administradores e o único acionista, acarretam responsabilidade ilimitada de todos êles" $\left({ }^{2}\right)$.

Parece-nos, data vênia, que essa interpretação é passível de crítica, pois, a ser exata, teríamos de admitir o instantâneo desaparecimento da personalidade jurídica da sociedade e, conseqüentemente, a automática confusão de patrimônios.

E' de notar, ad argumentandi, que a personalidade jurídica do ente social emerge da pluralidade de sócios subjacente ao ato de constituição.

Mas essa personalidade se desprende daquela causa originária e passa a encontrar o seu verdadeiro substrato no princípio da autonomia do patrimônio afetado a um fim.

Dêsse modo, na hipótese da sociedade unipessoal, poder-se-á admitir a continuidade da pessoa jurídica, não em função do número de acionistas reduzido à unipessoalidade, mas em função de um "patrimônio autônomo a que corresponde uma autônoma subjetividade jurídica" ${ }^{1}$ ).

A propósito da teoria da continuidade da personalidade, no que respeita ao fenômeno da sociedade unipessoal, parecem-nos judiciosas as ponderações de Arruda Correia, que a seguir transcrevemos:

"Efetivamente, a sociedade é o simples substrato em relação à personalidade jurídica; e como nem tôdas as oscilações do subsolo se repercutem na superfície, assim se concebe que a pernalidade permaneça indiferente às mutações de sua infra-estrutura.

E, com efeito, sabemos que a identidade da pessoa coletiva não é vulnerável nem sequer pela total substituição dos associados. E se os sócios resolverem transformar a sociedade, convolar de uma espécie para outra - tão profundas podem ser as modificações introduzidas dêsse modo no vínculo social, que será difícil, quando não totalmente impossível, identificá-lo ainda com o primitivo. No entanto, esta consideração não tem impedido a doutrina de ver na transformação da sociedade uma simples alteração estatutária, não sendo afetada por ela a pessoa jurídica social na sua identidade.

Ora, a permanência do ente coletivo para além de tão radical

(2) TRAJANO DE MIRANDA VALVERDE - "Sociedades por ą๊̨̃es", edição
Revista Forense, vol. II, pág. 128.

(1) ARRUDA CORREIA, ob. cit., pág. 328. mutação do vínculo social, importa que o tenhamos de conceber como alguma coisa de diferente da simples projeção dêsse vínculo - alguma coisa que, tendo nascido com o contrato de sociedade, dêle se desprendeu e autonomizou por completo. Alguma coisa que, exprimindo simplesmente um certo modo de ser da relação social, é todavia capaz de lhe sobreviver - para vir qualificar uma situação nova; algo, neste sentido, de necesssidade exterior à sociedade; um simples predicado que ao mesmo tempo se afirma como sujeito.

Mas se a pessoa jurídica social leva a sua independência ao ponto de suportar a extinção da primitiva sociedade - é só dar um passo mais, e teremos a explicação da sociedade unipessoal. De tal sorte a personalidade social afirma a sua autonomia em face da personalidade singular dos seus membros de ocasião, que a sua subsistência não está condicionada à perduração de uma efetiva pluralidade de sócios. A sociedade extingue-se, e o ente jurídico subsiste - mas como figuração, agora, de uma realidade diferente, como revestimento de um novo subtrato; não como ente corporativo, mas como simples personificação de um patrimônio.

Aliás, nem a mutação do substrato terá sido radical: pois a sociedade de responsabilidade limitada não é pura associação de pessoas, antes um dos pilares em que assenta a respectiva organização reside na autonomia e vinculação de um patrimônio. Este patrimônio separado e ligado a um fim é que representa o elemento às duas situações - o quid que permite unificá-las e dar, assim, à substância da personalidade jurídica um ponto de apoio suficiente" ${ }^{1}$.

9 - Em sentido contrário, poder-se-á argüir que tudo isso ainda paira no terreno movediço das interpretações doutrinárias.

Mas, de qualquer forma, já algumas conclusões poderemos tirar em proveito de nossa tese.

Tais conclusões são as seguintes:

I - Nas atividades da economia contemporânea a existência 子e sociedades unipessoais ou fictícias constitui fato que não comporra contestação.

I - Do ponto de vista doutrinário, torna-se possível estabelecer a condição e definir a natureza jurídica de tais sociedades.

III - A existência dêsse fenômeno e a sua intensidade nos últimos tempos, refletem uma lacuna no quadro do direito positivo, a qual poderá ser normalmente preenchida, uma vez instituída a emprêsa individual de responsabilidade limitada.

- Como, pois, recusar acolhimento ao novo instituto?

(1) ARRUDA CORREIA, obr. cit., págs. 334 e 335. 


\section{3 - A EMPRESA MERCANTIL MODERNA}

a) A emprêsa no duplo aspecto econômico e jurídico

1 - O vocábulo "emprêsa", em sentido genérico, designa uma atividade plurilateral organizada e dirigida a um determinado fim. Este poderá ser apreciado sob o tríplice aspecto social, econômico e jurídico.

2 - Em verdade, pode a emprêsa refletir uma atividade puramente social e que transcende ao âmbito da economia e do direito.

Mas, esta espécie não nos interessa, pôsto que não pretendemos. esboçar uma teoria geral sôbre o assunto.

3 - Considerada sob o ponto de vista econômico, a emprêsa é uma organização de caráter autônomo que, sob a direção de pessoa singular ou societária, tem por finalidade conjugar os fatôres da produção, com o fito, de lucro.

Sucinta análise dos vários elementos consubstanciados nesta fórmula, não só demonstrará o fundamento econômico da emprêsa como também poderá fornecer o critério a ser adotado para o estabelecimento de sua noção de ordem jurídica.

I - A idéia de emprêsa nos conduz imediatamente à de organização, isto é: complexo de bens e pluralidade de pessoas, sistemàticamente dispostos e proporcionalmente coordenados, para a obtenção de um fim pré-estabelecido.

II - A emprêsa, considerada como organização, possui um caratér autônomo. Esta autonomia resulta da existência de um patrimônio próprio; de um domicílio, que se não confunde com o do respectivo titular; de um objeto ou fim econômico; do uso privado de uma firma ou denominação sob que opera, etc.

III - E' a emprêsa dirigida pelo respectivo empresário, pessoa individual ou coletiva, que nela exerce funções de titularidade e que agirá diretamente ou através do competente órgão de administração.

IV - Na entrosagem da emprêsa são conjugados os fatôres da produção - natureza, trabalho e capital - de maneira harmônica e racional, a fim de que o processo produtivo possa oferecer um máximo de rendimento com um mínimo de sacrifício.

$\mathrm{V}$ - Por fim, ao mesmo tempo em que a emprêsa se destina a prestar serviços aos elementos externos que com ela se relacionam, também visa para si uma vantagem - o lucro - que, aliás, lhe constitui a característica econômica.

4 - Seria escusado lembrar que a definição por nós exposta e analisada não contará em seu favor com a opinião de uma grande corrente de eméritos doutrinadores, a qual, nestes últimos tempos, vem aprofundando o assunto, em tôda a sua extensão e complexidade. Contudo, para o objetivo dêste trabalho, contentamo-nos com aquela fórmula, aliás, por nós adotada há dez anos passados $\left({ }^{1}\right)$.

5 - Já salientámos que, delimitada a emprêsa em sentido econômico e de acôrdo com a teoria dos fatôres da produção, com os mesmos elementos que daí ressaltam poder-se-á estabelecer a sua definição, sob o aspecto jurídico.

$\mathrm{Na}$ verdade, é essa a opinião de ilustrados comercialistas, notadamente Lourenço Mosa, na Itália e, entre nós, Carvalho de Mendonça $\left({ }^{2}\right)$.

Entretanto o professor argentino Waldemar Arecha, em sua alentada monografia "La Empresa Comercial", considera inadmissível êsse critério e se propõe a formular uma nova definição, consentânea, aliás, com a teoria que expõe e amplamente defende.

Dêsse modo, após examinar as várias teorias expostas pelos comercialistas, inclusive a dos fatôres da produção a que nos filiámos, apresenta uma definição genérica, da maneira seguinte: "Empresa es la unidad en que se manifiesta la organización del trabajo plurilateral aplicado sobre la riqueza para producir un resultado" ( ${ }^{3}$ ).

Situando a emprêsa na esfera da atividade mercantil, acrescenta: "La empresa es comercial cuando intermedie en la circulación de los bienes, o en el trabajo ajeno, o en el cambio de crédito, o en el cambio de eventos, o cuando emplee valores industriales" $\left({ }^{4}\right)$.

Levantadas essas premissas, passa a formular a sua definição de emprêsa mercantil, assim enunciada:

"Empresa comercial es la unidad en que se manifesta la organización del trabajo plurilateral aplicado sobre la riqueza para producir un resultado, intermediando para ello en la circulación de los bienes, o en el trabajo ajeno, $o$ en el cambio de crédito, o en el cambio de eventos, o empleando valores industriales" $(\mathbf{1})$.

Reconhecendo, embora, a prolixidade dessa fórmula, declara $\odot$ insigne comercialista que a noção de emprêsa comercial está aí enquadrada com absoluta firmeza.

(1) MARTINS FILHO - "Noções de Economia Política", Editora Fortaleza, 1942. (2) Vide LORENZO MOSSA
(2) "Derecho Mercantil", trad. de Felipe J. Tenar ed. Uteha Argentina, Buenos Aires, vol. I, pág. 20; CARVALHo DE MENDONgA,
obr. cit., vol. I, pág. 492. obr. (3) WALDEMAR ARECHA - "La empresa comercial", Editorial Depalma, Buenos (4) Obres. cit., pág. 383. 
6 - Através da leitura da substanciosa monografia do professor Waldemar Arecha, em que o assunto é amplamente explanado e discutido em face das diferentes doutrinas esposadas pelos mais autorizados juristas - tem-se a nítida compreensão da alta importância e magnitude da emprêsa mercantil, na vasta esfera da vida econômica dos nossos dias.

E porque assim é, não seria possível, ou talvez oportuno, confinar tôda a matéria de direito comercial nas atividades da emprêsa?

Essa interrogação, já anteriormente formulada, se nos apresenta ainda mais insistente, motivo por que não nos furtamos ao desejo de renová-la.

7 - Em verdade, como judiciosamente acentua o professor Waldemar Ferreira - "Não poucos consideram ao direito comercial o direito da emprêsa. Passou esta, por isso e ainda por outras e mais poderosas razões políticas e sociais, para plano muito mais alto que o de simples organização dos fatôres produtivos (natureza capital e trabalho), ou seja exercício profissional de indústria ou comércio, transmudada em célula máter do organismo estatal.

O direito comercial, sustenta-se, ainda é o direito profissional por excelência. Êsse conceito fundamental não deve ser abandonado. Não pode, realmente, observou Maurice Chavrier, sonhar em volta ao critério puramente subjetivo e formalista da corporação ou casta. Importa, todavia, ter em conta o elemento profissional. Como, porém, salientá-lo? Por fatos exteriores. Pela atividade de quem o exerce. Pelo organismo que o caracteriza. Encaram-se, dêsse modo, ao mesmo passo, o comerciante, os atos de comércio, a organização e o exercício da profissão comercial. Ora, o que deflui dessas diferentes considerações, substituindo a do ato de comércio, é a idéia mais real de organismo mercantil - a de emprêsa. Foi ela que código comercial recente pôs em sua base, o rumeno. Foi ela que, no fundo, inspirou grande número de decisões francesas. A emprêsa constitui, atualmente, o verdadeiro critério da comercialidade. $\mathrm{O}$ direito comercial deve ser o das emprêsas. Essa idéia o unifica. Restitui-lhe seu caráter profissional, sem que se regresse ao direito de casta e de formalismo antigo. Ligam-se-lhes as noções de atos de comércio e de comerciante. Comerciante é o chefe da emprêsa, indivíduo ou sociedade, conforme o caso. Quanto aos atos de comércio, êles se reputam mercantis pela teoria do acessório, salvo alguns, verdadeiramente objetivos" ( 1 )

8 - Essas e outras razões, igualmente hauridas dos ensinamen-

(1) WALDEMAR FERREIRA - Instituiçóes de Direito Comercial"' Ed. Freitas Bastos, Rio - 1947, vol. I, págs. 118 e 119 ; cit. in nota 70, ML
"Evolution de l'idée de la commercialité (Paris, 1935), pág. 135. tos dos mestres ou resultantes de observação pessoal, colocam-nos ao lado dos que propugnam tenazmente pela disseminação da idéia de uma reforma radical e completa, no sistema do direito mercantil brasileiro, de modo a que tôda matéria comercial seja exatamente confinada nas atividades da emprêsa.

Inclinamo-nos a acreditar que não se trata de uma transforma"ção brusca e, sim, oportuna, necessária e que atende às exigências dos novos tempos.

A nova codificação do direito comercial que se pretende elaborar, tornar-se-á ainda mais completa se em seu âmbito fôr acolhido, como se impõe, o instituto da emprêsa individual de responsabilidade limitada.

\section{b) Esquema de uma nova classificação}

1 - Não definiu, o Código Comercial de 1850, a figura jurídica do comerciante. Enumerou apenas os que podem comerciar e os que estão proibidos de fazê-lo, em virtude de exercerem funções de ordem pública.

Daí se infere que a atividade mercantil, em caráter de profissão habitual, poderá ser praticada por qualquer indivíduo isoladamente, desde que tenha a livre administração de sua pessoa e bens, e que lhe não seja vedado exercer a mercancia.

2 - Dois ou mais indivíduos poderão igualmente convencionar o exercício do comércio, por meio de contrato de sociedade mercantil, de que emana uma pessoa jurídica distinta, isto é, o comerciante.

Note-se de passagem que o velho Código também não definiu - contrato de sociedade, lacuna posteriormente preenchida pelo Art. 1.363 , do Código Civil.

3 - A prática do comércio em nome individual, acarreta, para a pessoa do comerciante, a ilimitação da responsabilidade, quanto aos riscos inerentes ao negócio. Noutras palavras: o patrimônio da firma individual confunde-se com o patrimônio civil do comerciante, ainda mesmo que a emprêsa se agigante e econômicamente se personalize.

4 - Havendo, porém, contrato de sociedade, três hipóteses poderão advir, quanto ao gráu de responsabilidade assumida pelos sócios, em função do tipo societário adotado.

Dêsse modo, poder-se-á falar em sociedade de responsabilidade ilimitada, sociedade de responsabilidade limitada e sociedade de responsabilidade mista.

$20-$ R. D. $10^{\circ}$ Vol. 
5 - A tradicional classificação que as divide em dois grupos sociedades de pessoas e sociedades de capital - tem apenas uma importância de ordem histórica, pois que representa uma fórmula "mais brilhante do que justa", conforme observou Vivante ${ }^{1}$ ).

A propósito dêsse critério classificador, tão persistente quanto inexato, veja-se o comentário do professor Eunápio Borges, em judicioso trabalho recentemente publicado na Revista da Faculdade de Direito da Universidade de Minas Gerais ${ }^{(}{ }^{1}$.

6 - Particularizando as nossas considerações, como seria possível enquadrar, no sistema do direito brasileiro, a emprêsa individual de responsabilidade limitada?

7 - Reconhecemos que essa idéia encontra francos opositores, que se apegam a dois argumentos fundamentais: a) impossibilidade de uma nítida separação de patrimônios; b) possibilidade de fraude, na prática mercantil.

Ainda não é êste, porém, o momento de examinarmos a inconsistência dessa propalada argumentação.

8 - Por enquanto limitamo-nos a admitir que é possível o acolhimento da emprêsa individual de responsabilidade limitada, desde que lhe seja reconhecida personalidade jurídica, a igual do que ocorre em relação às sociedades comerciais.

Nesta hipótese, comerciante será a emprêsa, que se personaliza jurìdicamente, em função da autonomia do patrimônio afetado ao giro comercial, ou em virtude da declaração da vontade manifestada no ato de constituição.

Será isso lògicamente inconcebível? Qual a noção de personalidade, na linguagem peculiar à ciência do direito?

A essa altura, reportamo-nos ao ensinamento de Ferrara, consubstanciado nesta síntese admirável:

"A personalidade é um produto da ordem jurídica e surge por um reconhecimento do direito positivo. $O$ homem é uma pessoa não por natureza e sim por obra do direito. A qualidade natural do homem, como de um ente racional e capaz de vontade, é só a base ética, para que o direito de um certo estádio de cultura reconheça a todos os homens personalidade. Porém a subjetividade não é inata no homem, não é uma qualidade inerente ao indivíduo, senão uma realização ideal que sem a ordem jurídica é inconcebível. Em período anterior à organização estatal, o homem não é pessoa. E mesmo constituída a ordem jurídica, a história demonstra que por longo

(1) CESARE VIVANTE - "Trattato di Diritto Comerciale", col. II, pág. 84. in Revista da Faculdade de Direito da Universidade de Minas Gerais, n. 1, Outubro de 1949, pág. 27 e segs. tempo houve uma classe de homens aos quais se negava a qualidade de sujeito de direito - os escravos. E não é só isso: a personalidade também podia ser perdida, por uma condenação penal (morte civil) ou por uma adoção do estado religioso (vida claustral). E também nos indivíduos capazes, a personalidade se manifesta como uma quantidade variável, que pode ser reconhecida em mais ou menos larga medida. Històricamente não foram iguais, sob o ponto de vista jurídico, homens e mulheres, cristão e hebreus, nobres e vassalos, sendo que ainda hoje existe diferença entre nacionais e estrangeiros" (1).

9 - Não pretendemos discutir qual a doutrina preferível para justificar a personalidade jurídica da emprêsa individual limitada: - se a que preconiza a teoria da personificação do patrimônio, ou se a que defende a teoria da autonomia da vontade declarada no ato de constituição.

Apenas reconhecemos, com Trajano de Miranda Valverde, que "nenhum inconveniente advirá em se dotar o estabelecimento autônomo de personalidade jurídica, como, aliás, ocorre com as fundações" $\left({ }^{2}\right)$.

10 - Admitida a possibilidade de ser reconhecida personalidade jurídica à emprêsa individual de responsabilidade limitada e, pois, o seu acolhimento no quadro do direito positivo, passamos a formular o esquema seguinte:

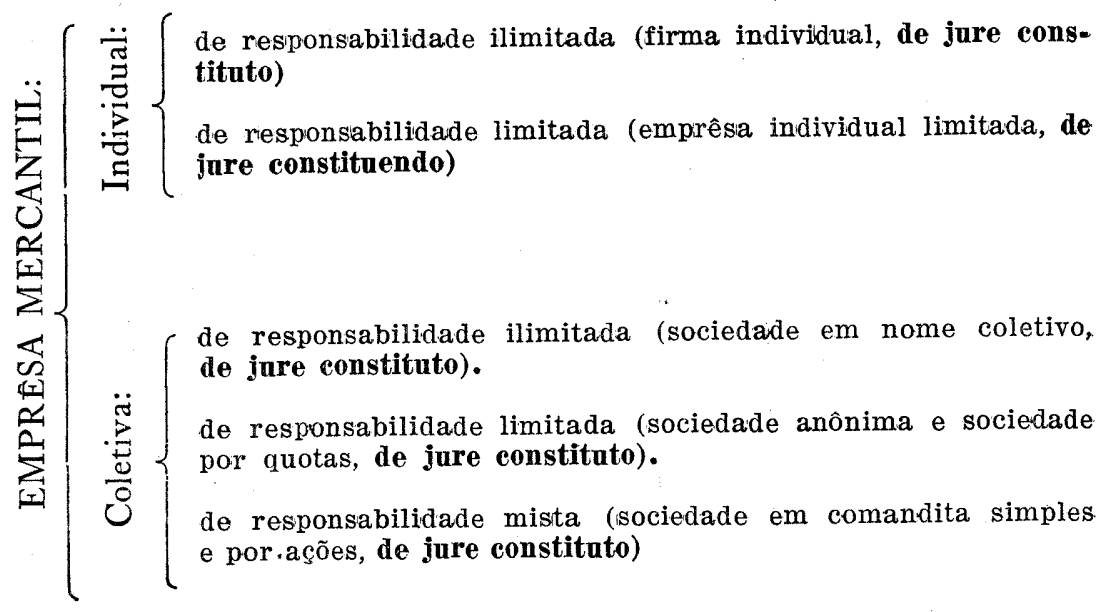

(1) Vide WALDEMAR ARECHA - "La empresa comercial", Ed. Delpelma, Buenos Aires, 1948, págs. 248 e 249, in nota.
(2) "Estabelecimento autônomo", in Revista Forense, vol. XCVI, ano XI, fascículo 486, pág. " 577 . 
O quadro acima, que elucida o nosso pensamento em matéria de emprêsa mercantil, exclui a sociedade de capital e indústria, a sociedade em conta de.participação e a sociedade cooperativa.

As duas primeiras em relação ao gráu de responsabilidade assumida pelos respectivos titulares, nada mais são do que emprêsas individuais de responsabilidade ilimitada.

A sociedade cooperativa, desde que lhe falta intuito especulativo, não é, a rigor, uma emprêsa mercantil.

\section{4 - A EMPRESA INDIVHDUAL DE RESPONSABILIDADE LIMITADA}

a) Doutrina e legislação

1 - A preocupação de se encontrar um meio normal e direto pelo qual possa ser estendido o princípio da limitação da responsabilidade ao comerciante singular, não é recente. Ao invés, êsse problema vem preocupando a doutrina desde o último decênio do século pretérito, notadamente na Alemanha, Âustria e Suíssa.

2 - Reunidos em assembléia os delegados da Associação Suíssa de Comércio, a 29 de Abril de 1893, um dos seus membros focalizou a necessidade de revisão do Código das Obrigações, insistindo em que se estudasse a convenincia de ser introduzido um dispositivo pelo qual se tornasse possível às emprêsas particulares limitar a responsabilidade de seu titular. ( $\left.{ }^{1}\right)$

Em 1895, o notável jurista Karl Wieland mostrou-se francamente favorável à extensão do benefício da limitação dos riscos à emprêsa de um único proprietário.

Depois, em 1910, o jurista austríaco Oskar Pisco, dedicando-se ao estudo das "one man companies", levantou várias questões de ordem jurídica atinentes à limitação da responsabilidade da emprêsa, chegando a elaborar anteprojeto de lei sôbre - "A responsabilidade limitada do comerciante individual".

3 - Baseado na doutrina de Pisco, o legislador do Principado de Liechtenstein, em 1926, tomou a iniciativa de acolher, no quadro do direito positivo, o instituto da emprêsa individual de rseponsabilidaade limitada. Efetivamente, é a matéria ali regulada no Código Civil.

Trata-se, é certo, de pequeno país, com uma população de doze a quinze mil habitantes e cuja extensão territorial apenas cobre uma área de $159 \mathrm{kms} 2$.

(1) Of. PAUL CARRY, obr. cit., págs. 25 e 26.

\section{$-305-$}

No entanto, essas razões não poderão constituir motivo desfavorável ao acolhimento do novo instituto, pois, como faz ver Suarez Ancorena - o pensamento jurídico não depende da extensão territorial, nem tampouco do poder econômico, político ou militar do país em que encontrou meios para a sua realização $\left({ }^{1}\right)$.

4 - Do ponto de vista doutrinário, não se justifica a afirmativa de que a experiência de Liechtenstein não tem encontrado seguidores.

Em 8 de Fevereiro de 1928, o professor suisso Paul Carry realizou, na Faculdade de Direito da Universidade de Genebra, uma conferência sôbre o título - "La responsabilité limitée du commerçant individuel". Neste excelente trabalho, publicado em folheto pela Faculdade de Direito mencionada, o assunto é estudado à luz de novos e ponderáveis argumentos, chegando o seu autor a conclusões favoráveis à adoção da emprêsa individual de responsabilidade limitada.

Dois anos depois - 1930 - o jurista espanhol J. Roig y Bergada houve por bem se ocupar do assunto, realizando importante conferência que fêz inserir, à guisa de anexo, em sua obra - "Sociedades de Responsabilidade Limitada".

5 - Ainda na Europa, além de inúmeros estudos publicados em revistas especializadas e firmados por ilustres mestres, notadamente italianos e alemães, a necessidade do reconhecimento legal da limitação dos riscos à emprêsa de um único titular, vem •determinando o aparecimento de substanciosas monografias, dedicadas exclusivamente à análise do assunto.

Dentre elas se destaca a de autoria do jurista Roger Ischer, sob a epígrafe - "Vers la responsabilité limitée du commerçant indivi duel", lançada à publicidade pela "Editions SPES S.A.", de Lausanne, em 1939.

E de salientar a importância que esta obra oferece para a solução doutrinal do problema, maximé porque o seu autor faz inserir, no capítulo VI, projeto de lei em que o novo instituto é disciplinado de maneira racional e precisa.

Ainda são dignos de menção o estudo do professor F. de Sola Cañizares - "L'entreprise individuelle à responsabilité limitée", recentemente publicada em Paris $\left(^{1}\right)$ e a excelente monografia do jurista português doutor Antônio de Arruda Ferrer Correia - "Sociedades Fictícias e Unipessoais", de cujas conclusões se infere a necessidade inelutável de uma revisão no quadro do direito positivo,

(1) Conferencia Nacional de Abogados, Santa-Fé, 1940, pkg. 288. Apud de Sola Canizares, "L'entreprise individuelle à responsabilité
de Droit Commercial, Ano 1. $1.03,1948$ - Paris.

ESCARRA "Revue Trimestrielle de Droit Commercial", publieada pelos professores JEAN 
a fim de que seja limitada, por meios normais e diretos, a responsabilidade do comerciante singular.

6 - É, porém, na República Argentina que o problema da emprêsa individual de resposabilidade limitada vem sendo suficientemente aprofundado e grandemente discutido.

Já em 1914, em um curso ministrado na Faculdade de Ciências Econômicas de Buenos Aires, sôbre o tema - "El capital, el crédito y la responsabilitad en el comercio", o professor A. Rivarola focalizou a possibilidade de criação da emprêsa individual de responsabilidade limitada, revestida de normas rígidas e capazes de assegurar os direitos de terceiros, como solução ao problema das sociedades anônimas fictícias, então muito generalizadas naquele país, onde, aliás, ainda não havia sido adotado o instituto da sociedade de responsabilidade limitada.

A partir de 1937, retornou o assunto à ordem do dia, passando a ser discutido com a maior intensidade, através de livros, folhetos, conferências e congressos.

Com efeito, em Setembro dêsse ano, o doutor Esteban Lamadrid publicou, na "Revista del Colegio de Abogados", interessante estudo em que estabelece as bases para a elaboração do projeto de lei referente ao novo instituto de direito mercantil.

No ano seguinte - 1938 - o senhor secretário da legação suissa em Buenos Aires, doutor Jaques-Albert Cuttat, em artigo divulgado pela imprensa, aflorou comentários acêrca da legislação da emprêsa individual limitada, vigorante no Principado de Liechtenstein, reportando-se, ainda, aos seus antecedentes doutrinários.

No mesmo ano, foi o assunto abordado na Universidade de la Plata, em um curso de trabalhos práticos ministrado pelos doutores Alberto Sordelli e Guillermo Ball Lima, sob a direção do professor Francisco Orione.

No primeiro Congresso de Direito Comercial Argentino, reunido em 1940, na cidade de Buenos Aires, após acuradas investigações de que resultou o pronunciamento de renomados juristas foi aprovada uma resolução no sentido de ser adotada a emprêsa individual de responsabilidade limitada.

No mesmo ano voltou o assunto a plenário, na Quinta Conferência de Advogados, reunida em Santa Fé, logrando aprovação da quase totalidade dos conferencistas, em virtude das judiciosas considerações dos juristas Francisco Orione, Lira Urqueta, Arturo Garcia Lopez e Carlos Suarez Ancorena.

Ainda em 1940, dois projetos de lei são formulados, sendo os seus autores o doutor Miguel A. Lancelloti e o deputado nacional Oscar Rosito.
Em 1942, o professor Rivarola deu publicidade a um estudo sob o título - "La empresa individual de responsabilidad limitada", o qual constitui um dos capítulos de sua obra - "Sociedades Comerciales" $\left({ }^{1}\right)$

No ano seguinte, o Instituto Argentino de Direito Comercial deliberou realizar uma conferência pública, a fim de ser debatido o assunto, tendo a mesma como presidente o jurista Carlos C. Malagarriga.

Nesse importante conclave foi aprovado o anteprojeto de lei instituindo a emprêsa individual de responsabilidade limitada, do qual é autor o emérito jurista e professor Waldemar Arecha, um dos mais eminentes defensores da idéia $\left({ }^{2}\right)$.

Ainda na República Argentina, que vem assumindo a liderança do movimento, manifestaram-se em favor do novo instituto em trabalhos recentemente publicados, Guillermo Ball Lima, Alberto Sordelli, Victor L. Cinollo Vernego, Hector M. Enz, Francisco Orione e vários outros insignes mestres da ciência jurídica.

7 - Noutros países latino-americanos a tese não tem sido lançada ao olvido.

Efetivamente, sôbre a necessidade da instituição da emprêsa individual de responsabilidade limitada, já se manifestaram, em monografias e trabalhos divulgados pela imprensa, o professor cubano Ernesto Dihigo; o jurista mexicano R. Cervantes Ahumad nhecido mestre uruguaio Fernandez Goyechea, que, aliás, se tem dedicado arraigadamente ao estudo do assunto, tornando-se um dos lídimos propugnadores da inovação ( ${ }^{1}$ ).

8 - No que respeita ao nosso país, mister é reconhecer que a tese não vem sendo discutida e aprofundada na proporção que está a exigir.

Aliás, a ela se reportou Trajano de Miranda Valverde, em trabalho doutrinário, sob o título "Estabelecimento autônomo", divulgado pela "Revista Forense", em Dezembro de 1943.

Após assinalar o fenômeno anormal das sociedades unipessoais ou fictícias, bem como as conseqüências daí resultantes, admite o autorizado jurista, a possibilidade de limitação dos riscos ao comerciante singular, filiando-se à teoria da personalização do patrimônio. Alude às vantagens de ordem econômica que poderão

(1) Edicão "El Ateneo", Buenos Aires - 1943, págs. 542 e segs. Estudio F. E. N. \& W. Arecha, Buenos Aires - 1942; e "EMPRESA LIMITADA" Debate público sobre el anteproyecto de ley redactado por encargo del Instituto Argentino de Derecho Co

(1) Vide - F. DE SOLA CANIZARES, trabalho cit., pág. 378. 
advir, em sendo adotado pelo direito positivo, com as necessárias reservas, o novo instituto de direito mercantil.

Por fim conclui que "a matéria está a exigir a crítica ponderada dos doutos".

É exatamente isso que nos tem faltado, pois, se voz autorizada. se levanta esporàdicamente para aflorar comentários acêrca da magnitude e importância desta tese, a quase totalidade dos nossos doutrinadores prefere apreciá-la dogmática e apriorìsticamente, ou então relegá-la ao completo esquecimento, o que é mais cômodo.

9 - Em conseqüência disso, apresentado à Câmara Federal, em Maio de 1947, o Projeto n. ${ }^{\circ}$ 201, permitindo a instituição de emprêsas individuais de responsabilidade limitada - não teve o assunto. a repercussão e o exame que seria de esperar.

$E$ desde que nos falta, em seu favor, a indispensável preparação psicológica, resultante da análise percuciente da doutrina, teríamos de verificar o que efetivamente aconteceu.

$\mathrm{Na}$ verdade, submetido o Projeto 201 à consideração das Coniissões de Justiça e de Indústria, da Câmara dos Deputados, obteve em ambas pareceres contrários.

10 - Mas, de qualquer forma, forçoso é reconhecer que o instituto da emprêsa individual de responsabilidade limitada, sôbre representar uma idéia em marcha, constitui imperativo indeclinável da economia moderna.

E porque assim é, impõe-se a necessidade impreterível de ser estudado e aprofundado, detidamente, na fase de elaboração do anteprojeto do novo Código Comercial.

b) De jure constituendo quid faciendum?

1 - Duas principais barreiras são simultâneamente opostas à idéia de criação da emprêsa individual de responsabilidade limitada. A primeira consiste em que uma tal limitação dos riscos do comerciante singular seria contrária aos princípios tradicionais sôbre o patrimônio. A segunda se fundamenta na pressuposição de que o novo instituto possibilitaria a mais deslavada fraude na prática mercantil, pelo que se tornaria prejudicial às operações fiduciárias, que constituem a base da economia contemporânea.

2 - Outros argumentos subsidiários ou menos sólidos são igualmente invocados para justificar a tenaz oposição dos tradicionalistas, via de regra obstinados em não admitir imediatamente a realidade dos fatos.

Entre nós, por exemplo, fundamentando o parecer da Comissão de Comércio e Indústria da Câmara Federal, contrário à instituição de emprêsas individuais de responsabilidade limitada, afirma categòricamente o seu ilustre relator:

"Na legislação estrangeira, segundo relata lealmente o próprio autor do Projeto, não encontrou agasalho ainda a idéia da organização de emprêsas individuais de responsabilidade limitada.

Seríamos, no caso, os inovadores, os iniciadores da audaz reforma do direito comercial.

Não nos parece, pelas razões expostas, que ganharíamos fama ou tiraríamos proveito em fazê-lo".

Como se vê, ignora-se por completo a vigência do instituto no Principado de Liechtenstein, fato, aliás, que vem despertando vivo interêsse por parte da doutrina de outros países mais evoluídos em matéria de cultura jurídica. E em vista disso, qualifica-se de "audaz" a inovação, cuja finalidade consiste em disciplinar de direito um instituto que já existe de fato, através de sociedades unipessoais e fictícias.

3 - Examinemos, porém, se a emprêsa individual de responsabilidade limitada é realmente contrária ao princípio da indivisibilidade do patrimônio.

Todos sabemos que já adquiriu foros de axioma a fórmula segundo a qual - quem se obriga, obriga o que é seu.

Mas, observe-se que esta noção não é absoluta, e sim relativa, pois que a própria lei estabeleceu, na esfera jurídica de cåda indivíduo, a categoria dos chamados direitos inalienáveis, impenhoráveis, intransmissiveis, etc., bem como criou a ficção da personalidade ju rídica, que nada mais é, no âmbito das relações de ordem privada, do que a possibilidade da destinação de um patrimônio a um fim específico.

4 - Por outro lado, importa salientar que o conceito de patrimônio ainda não se encontra suficientemente definido pela ciência.

Após assinalar esta circunstância, comenta Clovis Bevilaqua judiciosamente:

"A maioria dos autores considera o patrimônio uma universalidade de direito, isto é, uma unidade abstrata, distinta dos elementos que a compõem. Contra êsse modo de ver insurgem-se Fada e Bensa, achando inútil e contrária à realidade essa abstração, que nos arrasta para o domínio das ficções. Para êles, essa universitas juris sòmente aparece quando, para um fim determinado, a lei unifica os direitos e obrigações da pessoa, como no caso da sucessão hereditária ou de falência" $\left({ }^{1}\right)$.

(1) "Teoria Geral do Direito Civil", 2.a ediģ̃o, Liv. Francisco Alves, Rio - 1929, 
A seguir, ainda acrescenta o mestre Clovis:

"Outra questão, que envolve o conceito de patrimônio, é a de sabermos se êle pode ser múltiplo ou se há de, necessàriamente, corresponder um a cada pessoa. A doutrina corrente adota a segunda solução, embora, excepcionalmente, se mostrem casos em que o patrimônio sofra uma divisão, que $\dot{\epsilon}$. antes, a necessidade prática de impedir a junção de bens de procedência diversa.

Os casos apontados como excepcionais da unidade do patrimônio em direito civil são os de benefício de inventário, da separação dos bens concedidos aos credores da falência e da sucessão de bens do ausente. Nesses casos, não há uma situação definitiva. Enquanto se apura, deducto aere alieno, o que deve entrar para o patrimônio do sucessor, subsiste, não absorvido, o patrimônio do sucedendo, ainda que ambos se achem dentro da esfera da atividade jurídica de uma pessoa. Interêsses valiosos se interpõem, mantendo a distinção dos patrimônios, impedindo-lhes a natural unificação.

Fada e Bensa, em contrário, afirmam que êsses casos dados como excepcionais entram na regra comum, porque o patrimônio só se unifica para um fim determinado: e, segundo o exigir essa finalidade, ter-se-ão dois ou mais patrimônios" (2).

5 - A doutrina francesa estabelece entre a pessoa e o patrimônio a mais íntima ligação, condensando-a nas regras seguintes: " $10^{\circ}$ - Só as pessoas podem ter patrimônio, visto que só elas podem ter direitos e obrigaçóes; $2 .^{\circ}$ - tôda pessoa tem necessària mente um patrimônio, ainda que não tenha bens alguns, ainda que não tenha senão dívidas; $3 .^{\circ}$ - cada pessoa tem um só patrimônio, pôsto que em casos excepcionais, os ben de uma pessoa possam ser separados em duas massas, por uma ficção, em benefício de grupos de credores; $4^{\circ}{ }^{\circ}$ - o patrimônio é inseparável da pessoa, de tal sorte que ninguém pode transmitir o seu patrimônio durante a sua vida: essa transmissão só se opera com a morte da pessoa”. (1)

Mas esta doutrina, como acentua Cunha Gonçalves, "é vivamente contestada por outros escritores, especialmente italianos, segundo os quais o patrimônio não é inerente à pessoa, pois podem existir pessoas sem patrimônio, embora todos tenham capacidade patrimonial; nem é único, nem inalienável e indivisível, pois poderá uma pessoa ter dois ou mais patrimônios, ou pode um patrimônio ser dividido e alienado, sendo exemplos disto a responsabilidade limitada, a cessão de heranças, a aceitação de herança a benefício de inventário". ${ }^{(2)}$

(2) Obr. cit., págs. 211 e 212.

(1) Vide CUNHA GONCGALVES - "Tratado de Direito Civil", Coimbra - 1929. (2) Obr. cit., pág. 309
6 - Conforme se vê pelo exposto, a conceituação de patrimônio ainda é matéria movediça, no campo das perquirições doutrinárias.

Estas e outras razões levam-nos a acreditar que o tradicional princípio da indivisibilidade do patrimônio, predominante em alguns sistemas jurídicos, notadamente o francês - não será tão forte que justifique uma tenaz resistência aos novos rumos do ordenamento jurídico, determinados pela evolução da sociedade. Não é, em verdade, a rigidez ou a suposta invulnerabilidade dos princípios que devem sufocar os fatos da vida social, porque, ao invés, são êstes que fundamentam aquêles.

7 - Mas, vamos admitir, ad argumentandi, a invulnerabilidade daquele princípio, desprezando o pressuposto de que a noção de patrimônio está em função das necessidades sociais.

Estabeleçamos, preliminarmente, essas premissas:

I - É permitido, à pessoa individual, retirar uma parte de seu patrimônio e com ela concorrer para a formação de um certo tipo de negócio societário de responsabilidade limitada? - Sim.

II - Os proventos advindos das transações e o que resultar da liquidação da sociedade não representam direitos que permanecem incorporados ao patrimônio civil do associado? - Sim.

- Ora, se isso é admissível e, pois, disciplinado pelo direito positivo, como justificar que o indivíduo, isoladamente, fique impedido de limitar os riscos de uma emprêsa a que afeta certa porção de seu patrimônio, emprêsa, aliás, que adquire personalidade jurídica e passa a viver em função dela? Será isso contrário à idéia da unidade do patrimônio? - Acreditamos que não, pois, ao patrimônio civil do comerciante singular com limitação dos riscos permanecerão incorporados os direitos que tem sôbre os proventos da emprêsa e bem assim sôbre o que resultar de sua liquidação, a igual do que ocorre nas sociedades mercantís 'de responasbilidade limitada.

Dêsse modo, mesmo que o concenso geral admitisse, a título de necessidade indeclinável, a doutrina da unidade do patrimônio, seria enquadrar o novo instituto no âmbito do direito positivo, sem ferir a rigidez de tal princípio.

É que a emprêsa individual de responsabilidade limitada, adquirindo personalidade e dispondo de um patrimônio, adquire, conseqüentemente, esfera de atividade jurídica própria, inconfundível com a do respectivo empresário, o qual passa a exercer, sôbre a organização, funções de titularidade, de que resultam direitos incorporados ao seu patrimônio de ordem civil.

8 - Vamos, porém, admitir que tudo isso é artificioso e improcedente, em face do princípio da indivisibilidade patrimonial. 
Nesta hipótese, não poderia ser acolhida, a novidade legislativa, à guisa de mais uma exceção ao número já crescido das existentes?

Que é o instituto do abandono liberatório, se não uma derrogação do princípio de que - quem se obriga, obriga o que é seu?

Como conceder, em matéria de direito comercial marítimo, o benefício da limitação dos riscos ao comerciante singular e negá-lo, em matéria de direito comercial terrestre?

Ora, se é certo que salvaguardar a fortuna de terra dos riscos. inerentes à fortuna do mar, é exigência da própria natureza do negócio - por constituir incentivo à indústria da navegação, - certo. é também que, permitir a limitação dos riscos ao comerciante individual não só representará um incentivo à expansão dos negócios, como ainda atenderá a um forte imperativo da economia dos nossos. tempos.

9 - Mas, conforme vimos, além do argumento de que a inovação é contrária aos princípios latinos tradicionais, um outro é insistentemente propalado, se bem que, como o primeiro, careça de fundamento.

Com efeito, certa corrente de doutrinadores considera a tese. jurìdicamente admissível, mas afirma que êsse tipo de emprêsa será uma espécie de porta aberta à fraude na vida prática. Daí a conclusão de que se torna perigosa e, pois, desaconselhável a sua adoção pelo direito positivo.

Êste argumento, ao que nos parece, não terá fôrça suficiente para sufocar uma idéia em marcha e já em vias de concretização.

Seria lógico condenar uma nova fórmula legislativa que, atendendo aos interêsses da economia, objetiva disciplinar situações já existentes, só pela suposição de seu desvirtuamento na prática mercantil, por meio de atos de desonestidade?

Os que aceitam esta hipótese como sendo a mais viável e, sob a pressão dêste estado psicológico, propalam abertamente tal pensamento, não se recordam que, em oposição constante à boa fé garantia máxima das operações fiduciárias - está a argúcia impreterível dos indivíduos inescrupulosos, os quais tanto podem agir em nome individual como coletivamente.

Destarte, a possibilidade de fraude, na trepidação da vida econômica, jamais deixará de existir, com ou sem a limitação dos riscos do estabelecimento do comerciante singular.

Seria, pois, inacreditável estacionasse o ordenamento jurídico diante de um obstáculo dessa natureza.

10 - Se isso é verdade, quais as diretrizes que devem orientar o legislador de 1950 , em face da nova codificação de nosso direito comercial? De jure constituendo quid faciendum?
Sendo o instituto da emprêsa individual de responsabilidade limitada um problema de real importância, deve ser solucionado com uma sismples recusa formulada apriorìsticamente?

Seria cabível permanecermos reservados em relação a um assunto de tamanha magnitude, sob o pretexto de problemáticas dificuldades ou sob o argumento de que o exemplo de Liechtenstein não tem encontrado seguidores?

- Pensamos diferentemente e daí a razão de ser dêste trabalho.

Não nos move o propósito de fazer luzes sôbre as obscuridades reinantes nem tampouco a de traçar os lineamentos basilares do instituto.

Pretendemos, porém, reclamar para êle o estudo aprofundado e a crítica percuciente dos doutos juristas desejosos de traçar novos rumos ao sistema do direito comercial brasileiro.

Admitimos a realidade dos fatos e, em vista disso, reconhecemos que a emprêsa do comerciante singular com limitação dos riscos, constituirá o único meio normal e lógico de ser evitada a propagação das sociedades unipessoais ou fictícias, que ora se multiplicam em tôda a extensão do território nacional.

Pelo cotejo dos antecedentes doutrinários de muitos países e pelo exame de vários projetos de lei já elaborados, notadamente na República Argentina - impõe-se-nos a convicção de que, analisado sob qualquer aspecto, o instituto da emprêsa indivigdual de responsabilidade limitada está em condições de ser adotado pelo novo Código Comercial do Brasil.

\section{CONCLUSÃO}

\section{DEBATE EM SESSÃO PLENÁRIA E CONSEQUUENTE PRONUNCIAMENTO DO CONGRESSO JURIDICO}

No decorrer dêste trabalho procuramos aflorar vários assuntos relacionados. diretamente com a tese inicialmente enunciada.

Em considerações gerais, salientamos que as leis, tal qual os indivíduos, sofrem também a ação do tempo, pelo que necessitam ser reajustadas periòdicamente. Nessa situação se encontra o Código Comercial brasileiro que, promulgado em 1850, não mais corresponde às exigências dos novos tempos. Várias tentativas de reforma já foram iniciadas, a partir do segundo decênio dêste século, das quais procuramos destacar o "Esbốço" Florêncio de Abreu, recentemente elaborado. Aplaudimos, em tese, a valiosa cooperação do ilustre jurista, na solução de problema de tamanha magnitude. Contudo, dissentimos de sua orientação doutrinária, no que tange 
à confinação da matéria comercial, que desejamos ver aglutinada em tôrno das atividades da emprêsa.

Também admitimos que não existem razões jurídicas decisivas contra as chamadas sociedades unipessoais, mas que se trata de meio indireto e, pois, anormal da limitação dos riscos do comerciante singular. Em vista disso, parece-nos aconselhável chegar a êsse fím diretamente ou seja pela adoção do instituto da emprêsa individual de responsabilidade limitada, com o que discorda categòricamente o autor de "Esbôço".

Em defesa de nossa tese, procuramos demonstrar a pressão dos fatos sôbre a lei em várias fases da vida econômica, daí resultando a tendência de limitação da responsabilidade, que ora se dirige em direção da emprêsa do comerciante singular.

A existência e generalização de sociedades fictícias ou unipessoais evidencia positivamente uma lacuna no quadro do direito positivo e, pois, reflete mais uma revolta dos fatos contra o Código.

Analisando a emprêsa mercantil sob o duplo aspecto econômico e jurídico, tentamos salientar a grande importância de que ela se reveste na atualidade, pelo que nos inclinamos a admitir a necessidade da confinação de tôda a matéria comercial na ampla esfera das suas atividades. Acreditamos não se tratar de "transformaçãobrusca" e, sim, oportuna e necessária, pois que atende aos imperativos da economia moderna. Conseqüentemente, a nova codificação ora desejada, tornar-se-á ainda mais completa se em seu âmbito fôr acolhido, como se impõe, o instituto da emprêsa individual de responsabilidade limitada.

Nessa convicção, passamos em revista o sistema do direito comercial vigorante em nosso país, no que respeita à figura jurídica do comerciante, pessoa individual ou societária. E atendendo ao gráu de responsabilidade que os membros titulares assumem para com a organização, formulamos o esquema de nova classificação das emprêsas mercantis, nêle incluindo a do comerciante individual com limitação dos riscos, de jure constituendo, desde que lhe é possível reconhecer personalidade jurídica, a igual do que ocorre em relação às sociedades comerciais.

Prosseguindo nesșa ordem de idéias, passamos a mencionar os antecedentes legislativos e doutrinários que justificam ou exigem um exame mais aprofundado da novidade legislativa, notadamente neste momento em que se cogita de elaborar nova codificação de nosso direito comercial.

A seguir, tentamos demonstrar que o instituto da emprêsa individual com limitação dos riscos não é contrário aos princípios latinos tradicionais sôbre o patrimônio, nem pode ser considerado prejudicial do ponto de vista de sua aplicação na prática, sob o funda- mento de constituir incentivo à fraude. E mesmo na hipótese de ser considerado derrogatório do princípio da indivisibilidade do patrimônio poderia ser admitido à guisa de mais uma exceção daquele. princípio, conforme ocorre em relação ao instituto do abandono liberatório, já existente no âmbito do direito comercial marítimo.

Por último, fizemos ver que, sob qualquer ângulo em que seja encarada, a emprêsa individual de responsabilidade limitada pode e deve ser acolhida no quadro do direito positivo.

Não tivemos a preocupação de traçar os lineamentos basilares. do novo instituto, de vez que existem vários projetos de lei preconizando a sua adoção, inclusive um no Brasil. Apenas nos limita mos a solicitar para êle o estudo mais aprofundado e a crítica serena dos eméritos juristas que ora se reúnem em Congresso, com o lou vável objetivo de, preferencialmente, estabelecer as diretrizes que devem nortear o legislador, na formulação do novo Código de Comércio.

Em conclusão, propomos à Egrégia Comissão Executiva do Congresso Jurídico comemorativo da passagem do Cinqüentenário de fundação da veneranda Faculdade de Direito da Universidade do Rio Grande do Sul - seja objeto de discussão em sessão plenária a tese que ofa apresentamos, para que, em caráter oficial, se decida sôbre a conveniência ou inoportunidade da inclusão do instituto da emprêsa individual de responsabilidade limitada, no sistema do nosso Direito Mercantil. 


\section{A $\mathrm{N} E \mathrm{XOS}$}

PROJETO $201-1947$

\section{PERMITE a constitricão de emprêsas individuais} de responsabilidade limitada; tende pareceres contrários das Comissóes de Justiça e de Indústria.

O Congresso Nacional decreta:

Art. 1. Qualquer pessoa capaz de exercer o comércio poderá constituir emprêsa em nome individual limitando a sua responsabilidade pelos negócios da mesma, ao valor do capital declarado.

Art. 2.0 A essas emprêsas é veldado o comércio bancário, o de seguros e o de capitalização.

Art. 3. Embora civil o objeto do negócio, a emprêsa ficará equiparada às sociedades comerciais e sujeitas às formalidades e às obrigações dos comerciantes, sendo-lhe aplicável a legislação comercial.

Art. $4^{\circ}$ A constituição da emprêsa se fará por escritura pública ou particular em que conste:

a) nome, nacionalidade, estado civil, idade, profissão e domicílio do proprietário e número da carteira de identidade, com designação da repartição expedidora;

b) a denominação contendo o nome por extenso ou abreviado do proprietário, precedido ou seguido da declaração - Emprêsa Individual de Responsabilidade Limitada, ou nela intercalado;

c) a sede da administração e dos estabelecimentos em que se exerç a atividade da emprêsa não sendo simples depósito;

d) o objeto da atividade:

e) o capital nunca inferior a $\mathrm{Cr} \$ 500.000,00$, realizado no ato da constituição, indicando-se a forma por que foi realizado;

f) transcrição do documento comprobatório da realização do capital.

data dos balanços semestrais:

h) quota dos lucros líquidos apurados' em cada balanço, não inferior a $10 \%$ destinada a constituir fundo de reserva;

i) retirada mensal pro-labore feita pelo titular da emprêsa, não superior ao permitido pela lei do impôsto de renda à conta de despesais gerais

j) expressa declaração da responsabilidade limitada.

Art. 5. ${ }^{\circ}$ A denominação na forma da letra $\mathbf{b}$ do artigo anterior será usada obrigatòraimente em todos os documentos, papéis, anúncios, reclames e outros, sob pena das conseqüências adiante declaradas.

Parágrafo único $\mathrm{Na}$ correspondência telegráfica será permitido usar como assinatura, o enderêço telegráfico ou substituir aquela declaração pelo nome do proprietário acompanhado da palavra "limitada".

Art. 6.o Para se fazer o registro é indispensável apresentar o documento que prove a realização do capital, na forma prescrita neste artigo.
§ $10^{\circ}$ o capital realizado em dinheiro ou em títulos ao portador, será depositado em banco, em nome da emprêsa.

\& $2 .^{\circ}$ O capital representado por bens moveis ou titulos nominativos, realizado com a transferência dos mesmos à emprêsa.

\& 3.0 0 capital representado por imoveis, serb averbar no respectivo registro a đeclaração do proprietário, da sua deliberação de transferir a propriedade para a empresa.

$\$ 4 .^{\circ} 0$ documento de depósito, a transferência e a averbação a que e referem os parágrafos anteriores, mencionarão que a emprêsa está "em organização".

\& 5.0 Feito o registro, o proprietário da emprêsa regularizará a situaão dos bens anteriormente referidos, transferindo-se regularmente para patrimônio dela suprimida a declaração "em organização".

Art 7. A emprêsa não poderá iniciar as atividades nem praticar Art. tidão do registro.

Parágrafo único. A publicação se fará de cópia autenticada pelo re gistro do comércio e esta será fornecida depois de comprovado o cumprimento do disposto no $\$ 5 .^{\circ}$ do artigo $66^{\circ}$.

Art. 8.0 Os lucros da emprêsa pertencem ao proprietário, mas não serão retirados, nem creditados a êle sem o prévio desconto da quota destinada ao fundo de reserva.

o desconto deixará de ser obrigatório quando o fundo de reserva atingir $50 \%$ do capital e voltará a ser feito quando se verificar diminuição. Art. 9. 0 capital poderá ser aumentado ou diminuido mediante escitura pública ou particular arquivada na forma da escritura de constituição. A diminuição não será permitida antes da publicação do arquivamento e não prejudicará os credores existentes nessa época. capital e fundo de reserva já realizado, o proprietário é obrigado a convocar credores, expondo-lhes a situação, os motivos dos prejuízos propondo a forma da liquidação dos débitos.

Não concordando a maioria dos credores calculada pelo valor dos créitos, a cmprêra entrará em liquidacão ou será declarada a falência se houver títulos vencidos de dívida líquida e certa.

Parácrafo único. Na liquidação ou falência, os credores da emprêsa erão atendidos prefentemente pelo ativo da mesma.

Art. 11. A responsabilidadde do proprietário se tornará ilimitada:

a) sendo a falència declarada culposa ou fraudulenta;

b) credores ou de que resulte prejuízo para êles;

c) não sendo obedecidas as disposições dos artigos $8 . .^{\circ}$ e 10

d) provado que o capital não foi totalmente integralizado ou foram dados aos bens que o constituíram valor exagerado;

) não se fazendo balanço nas epocas determinad

Art. 12. A responsabilidade será ilimitada em qualquer negócio em que se tenha omitido a declaração exigida no art $3 .^{\circ}$, salvo prova de que outra parte não foi nem podia ser.iludida.

Art. 13. E' equiparado ao crime de estelionato e punido com as penas correspondentes, a falsa declaração de estar realizado o capital, o levantamento do depósito ou cancelamento da averbação de que tratam os §§ 2 e 3 do art. $60^{\circ}$

Art. 14. Revogam-se as disposiçóes em contrário.

Sala das Sesisões, 21 de maio de 1947. - Freitas e Castro.

21 - R. D. 1.० Vol 


\section{JUSTIFICAC̨ÃO}

Há muito se faz sentir entre nós a falta de uma lei que permita regulamente a criação de emprêsas individuais de responsabilidade limitada.

A limitação de responsabilidade das pessoas que compõem uma detelminada sociedade, tem sido fator de iniciativas proveitosas para o desenmolvimento da economia do pais.

Tôłdas as legislações, reconhecendo tais vantagens, têm admitido a limitação da responsabilidade individual nas sociedades anônimas, nas sociedades em comandita e nas sociedades por quotas de responsabilidade limitada.

São notórios os benefícios colhidos dessa política. Nem todos têm a coragem precisa para arriscar numa emprêsa comercial ou industria a integralidade do seu patrimônio que representa a segurança econômica da família. A responsabilidade limitada facilita as iniciativas.

Nota-se em nosso direito uma falha que, aliás, é da legislação da quase totalidade dos países civilizados. Não temos uma lei que permita a criação de emprêsas individuais de responsabilidade limitada.

o mesmo princípio e as mesmas razões que justificam a limitação da responsabilidade individual em diversos tipos de sociedade, se aplicam a esisas emprêsas. Duas pessoas podem tentar um empreendimento sem arriscar a totalidiade do seu patrimônio; uma delas isoladamente não o podo fazer.

A distinção cada vez mais nítida que se faz entre o patrimônio da emprêsa e o patrimônio particular dos seus proprietários, cabalmente demonstra a sem razão dessa restrição.

o pior é que fàcilmente se burlam as disposições legais. Inúmeras "sociedades" existem apenas na forma exterior, pois realmente se compõem de um único indivíduo.

Não é só em nosso pais; os inglêses chamam a essas "sociedades" que se formam à sombra da lei, mas contra ela, "one man company" e os alemães, "einmanngeselschaft". Uma pessoa forma sociedade anônima e consegue que sels outras figurem, por favor, como acionistas, titulare de uma ação cada uma. Nas sociedades por quotas, o verdadeiro proprietário figura no contrato com a quase totalidade do capital, dando a terceiro uma quota que representa parte insignificante e ridícula do mesmo.

$\mathrm{Na}$ realidade, as emprêsas individuais existem, embora de formação. contrária à lei.

o mais não advém do fato em si, mas dos abusos que se podem cometer por meio de tão fácil burla às exigências da lei. Muitas dessas sociedades aparentes, têm vivido e prosperado, gozando de crédito nos bancos e de bom conceito na praça.

Diante da realidade dos fatos, em face dos princípios que regem o ins tituto de limitação de responsabilidade, é preferível que o legislador dis cipline a matéria evitando a ação dos aventureiros e de pessoas inescrupulosas.

Há relativamente pouco tempo, o "Instituto Argentino de Derechø Comercial" se preocupou com essa matéria e traçou regras julgadas indispensáveis a uma boa disciplina da mesma.

o projeto que apresento se inspirou no trabalho dêsse Instituto, in- troduzidas algumas modificações que me pareceram necessárias para melhor correspondência com o nosiso meio.

Sala das Sessões, 21 de maio de 1947. - Freitas e Castro.

A Comissão Executiva, cumprindo o disposto no art. 167 do Regimento Interno, opina no sentido de que seja julgado objeto de deliberação o projeto apresentado pelo Sr. Freitas e Castro, permitindo a constituição de emprêsas individuais de responsabilidarde limitada.

Sala da Comissão Executiva, em 21 de maio de 1947. - Samuel Duarte. - Munhoz da Rocha. - Pedro Pomar.

PARECER DA COMISSÃ̃O DE CONSTITUIC̨ÃO E JUSTIÇA

Não nos parece impreterivel a necessidade da promulgação de uma lei permitindo a constituição de emprêsas individuais de responsabilidade ilimitada, segundo preconiza o projeto número 201 de 1947 , do ilustre Deputado Sr. Freitas e Castro.

E' que a matéria da aludida proposição já existe implicitamente contida no Código Comercial e nas providências formuladas no decreto n. 916 de 24 de outubro de 1890 , em relação direta com alguns dos dispositivos que o expressam.

Bem verdade é que o projeto encerra disposições especialíssimas, mas não menos evidente é que alterada a forma presentemente observada na lei, quanto à constituição e funcionamento das emprêsas individuais, por igual ter-se-ia de atualizar também, certos institutos legais atinentes a diversas outras emprêsas, de sorte que a respectiva legislação lograsse, por seu turno, colocar-se ao mesmo nivel das aquisiçốes mais adiantarlas da moderna ciência jurídica, reclamados pelo progresso das atividades mercantis.

Em razão do que entendemos que a lei vigente pode aguardar, sem que dêsse retardamento resulte prejuizo sensivel, a reforma do código de 1850, que sem dúvida afirmará o momento de sua evolução inelutável.

Sala das Sessões da Comissão de Constituição e Justiça, junho de 1947 - Agamenon Magalhães, Presidente. Graccho Cardoso, Relator. - Josequim Ramos. - Soares Filho. - Antônio Feliciano. - João Agripino, com restrições. - Afonso Arinos, com restrições.

\section{PARECER DA COMISSÃO DE INDÚSTRIA}

O Projeto n.o 201, de 1947, de autoria do ilustre Deputado Freitas e Castro permite e regula a constituicão de emprêsas individuais de responsabilidade limitada.

Opinando sôbre o mesmo, a douta Comissão de Constituição e Justiça já se pronunciou pela rejeição.

$\mathbf{E}$ outro não é, também, o nosso parecer. Consideramos inconveniente, sumamente perigoso para o interêsse dos que comerciam, estabelecer-se um tipo de emprêsa, no qual o indivíduo, pondo em jôgo apenas determinado capital, pode assumir compromissos que de muito superam a êste. Se os seus bens particulares não ficam obrigados pelos atos praticados na direção da emprêsa, êle não terá, em muitos casos, a cautela e a diligência necessárias aos que lidam com a fortuna alheia. 


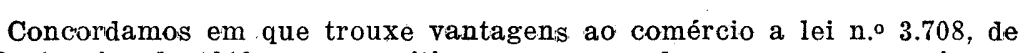
:0 de janeiro de 1919, que permitiu a um grupo de pessoas se associarem para negociar, restringindo sua responsabilidade y cota de capital subscrito. Mas aí se trata de mais de um associado, circunstância que, por si só, já constitui um freio à fraude. Depois, justifica-se plenamente que alguém, formando uma sociedade, mas não participando de sua direção, resguarde seus bens particulares de prejuízos que decorram de atos praticados por outrem.

Estabelecer-se, porém, determinauda pessoa com um negócio, quẻ ela própria dirige e controla, sem que sua responsabilidade seja ilimitada, afigura-se-nos esdrúxulo e arriscado.

Os tratadistas que compulsamos consideram a responsabilidade ilimitada dos bens dos sócios gerentes pelas obrigações por êstes contraídas em nome da sociedade, a maior garantia para as transações comerciais.

Vivante, depois de refletir que esisa responsabilidade tem origem histórica, remontando à Idade Média, acentua que a mesma se justifica plenamente ainda boje. (Instituicốes de Direito Comercial, trad de J. Alves mente ainda boje. (Inst

Entre nós, quando Nabuco de Araújo, Ministro da Justiça, em 1865, propôs se permitisse a constituição de sociedades de responsabilidade limitada, teve sua sugestão combatida pelo Conselho de Estado, através a voz dos Viscondes de Uruguai, Jequitinhonha e Itaboraí, de Pimenta Bueno e Sousa e Melo. (Apud Alfredo Russel, Direito Comercial, T. I. pág. 362).

Só em 1919, por iniciativa do Deputado Joaquim Luiz Ossório, teve ingresso em nossa legislação o tipo de sociedade referido. $\mathrm{E}$ assim mesmo, contra opinião do nosso mais acatado comercialista J. X Carvalho (a) "a Mendonça, por entender que "a sua aldmissão romperia a tradição, pertura 0 nosso sistema e nâo traria outras vantagens mais positivas alem de Direito Comercial Brasileiro, V. III. pág. 55, nota 5 do n. ${ }^{\circ}$ 573).

$\mathrm{Na}$ legislação estrangeira, segundo relata lealmente o próprio autor do Projeto, não encontrou agasalho ainda a idéia da organização de emprêsas individuais de responsabilidade limitada.

Seríamos, no caso, os inovadores, os iniciadores da audaz reforma do direito comercial.

Não nos parece, pelas razões expostas, que ganhariamos fama ou tiraríamos proveito em fazê-lo.

Sala da Comissão, em 14 de julho de 1947. - Hurgo Carneiro, Presidente, vencido. - Amando Fontes, Relator. - José Varela, vencido. dente, vencido. - Amando Fontes, Relator. - Jose Varela, vencido. vares do Amaral - Daniel Faraco, vencido. - Ari Viana.

NOTA: - O ilustre Deutado maranhense Snr. Luiz Carvalho, membro da Comissão de Indústria e Comércio, não compareceu à reunião em que foi discutido $e$ votado o Parecer Amando Fontes. Na reunião seguinte, como consta de ata, declarou que, se presente estivera, teria votado pelo como consta de ata, declarou que, se presente estivera, teria votado pelo Projeto n. 201, do Sr. Freitas e Castro. Esclareceu que, professor d direito comercial na Faculdade de Direito de S. Luiz, sempre lamentou, em preleções aos seus alunos, que o legisladior brasileiro ainda não houvesse cogitado de legislar sôbre a responsabilidade limitada fora do re gime societário.

\section{RELATÓRIO E PARECER}

Relator: PAULO BARBOSA LESSA

\section{APRESENTAÇÃO E DEBATES EM PLENÁRIO}

O SR. PRESIDENTE - Waldemar Ferreira - (imediatamente após à discussão da tese "Algunas cuestiones mercantiles ante merecho", do Prof. Salvador R. Perrotta, de Buenos Aires) el ninguém mais quiser fazer uso da palavra, cedo-a ao ilustre autor Se ninguem "LIMITACÃO DA RESPONSABILIDADE DO COMERda tese "LIMTA CIANTE INDIVIDUAL", Prof. Antônio Martins Fin o Prof. Antônio Martins Filho.

O SR ANTÔNIO MARTINS FILHO - Senhor Presidente, Senhores Congressistas. Minhas senhoras e senhores. Cedendo aos impulsos de um desejo irresistível, dispus-me a ventilar aqui um impulsos de um desejo de assunto que me parece de grande magnitude e que, por

Para orientar a votação do plenário quanto à conclusão defendida em minha tese - Limitação da responsabilidade do comerciante dida suas individual - permito-me a libei salientar o meu ponto de vista, se passagens, com o que procura bem que tenha conhecimento (o que, alás, constrange) da opinião do ilustre mestre professor Wácía à inovação.

De início são por mim apresentadas as seguintes proposições:

a) A emprêsa individual de responsabilidade limitada, repre- A empresa individu fase do processo evolutivo da limitação sentando a útima fé insistentemente reclamada pelos agentes da atividade econômica dos últmios tempos.

b) Recusando-a de direito, não evitará o legislador a existência de fato dessa espécie de emprêsa, que passa a funcionar sob forma de sociedade unipessoal ou fictícia.

c) Atendendo a que se trata de problema de ordem técnica e. dada a importância e complexidade de que o assunto se reveste, torna-se imprescindível o seu estudo e discussão em maior amplitude, para que se decida sôbre a conveniência ou inoportunidade de sua inclusão, no sistema do nosso direito positivo. 
Parece-me que a limitação da responsabilidade, em matéria contratual, está realmente se dirigindo para a emprês em matéria ciante singular. Tendo o seu ponto de partid emprêsa do comerreito Romano, eis que a seguir surgiu partida na societas, do Ditivo, na qual, de um certo modo, já se a sociedade em nome cole mitação da responsabilidade, não ja se acentuava o princípio da lipara com terceiros, mas com rân quanto às relações estabelecidas da corporação. A seguir,

determinaram o aparecim ordem social e, principalmente, econômicas, originou a sociedade em comanditatrato de pacotilha, de que se estágio da limitação dos riscos Ex E - fato que representa novo a atingir as relações externas da verdade, tal limitação passou certa classe de sócios assumes da sociedade, atendendo-se a que enquanto que outra apenas se responsabilade ilimitada e solidária, que se obrigou para com a socieedade

Como terceiro cstá a socieedade.

riscos, depara-se-nos a sociedade anôno evolutivo da limitação dos motivado por razões de ordem econômica, cujo aparecimento é sentam do que a pressão dos faconomica e que nada mais repreclinável necessidade de tor fatos sôbre a lei. Com efeito, a indementos de grande vulto determinou, dessa espécie de sociedade, que de conforme sabemos, o advento cremento, notadamente ae, que de logo tomou extraordinário in-

Depois, ainda ne a partir do século XIX...

lução da limitação dos riscos, adveio o nítida do processo de evoquotas de responsabilidade limitadio o instituto da sociedade por ao nosso direito positivo or iniciative, no Brasil, foi incorporado Grande do Sul. Acredito não

anônima e o da sociedae por em que o instituto da sociedade utilizados para que os agentes quotas vêm sendo constantemente um fim indireto. E que não possibilitade mercantil possam atingir limitação da re. E que não possibilitando, o direito constituído, a cada momento, não só no nosso país como individual, aparecem, sociedades chamadas unipessoais ou fictícias em vários outros, as

Dêsse modo unessoais ou fictícias.

Carry, numa conferência proferida cia com a observação de Paul a utilização do tipo sociedade anônimenebra, no ano de 1928 fim indireto é fato que representa, evidentema tornar possível um direito positivo.

Noutras par

idéia da relevância do assunto que pretendistas, poderei dar uma
Em considerações gerais, pröcurei salientar que as leis, tal como os indivíduos, sofrem também a ação do tempo, pelo que necessitam ser periòdicamente reajustadas. Nessa situação, com efeito, encontra-se o Código Comercial Brasileiro, que, promulgado em 1850, não mais corresponde às exigências dos novos tempos. Várias tentativas de reforma já foram iniciadas, notadamente a partir do segundo decênio dêste século, culminando com o Esbốço do ilustre Desembargador Florêncio de Abreu,' recentemente publicado. Aplaudimos, $\mathrm{em}$ tese, a valiosa contribuição do eminente jurista, na solução de problema de tamanha magnitude. Dissentimos, porém, de sua orientatação doutrinária no que tange à confinação da matéria comercial, que desejamos ver aglutinada em tôrno das atividades da emprêsa. Também admitimos que não existem razões jurídicas decisivas contra as chamadas sociedades unipessoais, mas que se trata de um meio indireto e, pois, anormal da limitação dos riscos do comerciante singular. Em vista disso, parece-nos aconselhável chegar a êsse fim diretamente ou seja pela adoção do instituto da emprêsa individual limitada, com o que discorda categòricamente o eminente autor do Esbôço.

Em defesa de nossa tese, procurámos demonstrar a pressão dos fatos sôbre a lei, em várias fases da vida econômica, daí resultando a tendência de limitação da responsabilidade, que ora se dirige em direção da emprêsa do comerciante singular.

Analisando a emprêsa mercantil sob o duplo aspecto econômicojurídico, tentámos demonstrar a grande importância de qủe ela se reveste na atualidade, pelo que nos inclinamos a admitir a necessidade da confinação de tôda a matéria comercial na ampla esfera das suas atividades. Não se trata de "transformação brusca" e, sim, oportuna e necessária, pois que atende aos imperativos da economia moderna. Conseqüentemente, a nova codificação, ora desejada, tornarse-á ainda mais completa se em seu âmbito fôr acolhido, como se impõe, o instituto da emprêsa individual de responsabilidade limitada.

Nessa convicção, passamos em revista o sistema do direito comercial vigorante em nosso país, no que respeita à figura jurídica do comerciante, pessoa individual ou societária. E, atendendo ao gráu de responsabilidade que os membros titulares assumem para com a organização, formulamos o esquema de nova classificação das emprêsas mercantís, nêle incluindo a do comerciante individual com limitação dos riscos, de jure constituendo, desde que the é possível reconhecer personalidade jurídica, a igual do que ocorre em relação às 'sociedades comerciais.

Prosseguindo nessa ordem de idéias, passamos a mencionar os antecedentes legislativos e doutrinários que justificam ou exigem um rexame mais aprofundado da novidade legislativa, notadamente neste 
momento em que se cogita de elaborar nova codificação de nosso Direito Comercial.

A seguir, tentamos demonstrar que o instituto da emprêsa individual com limitação dos riscos não é contrário aos princípios latinos tradicionais sôbre o patrimônio, nem pode ser considerado prejudicial do ponto de vista de sua aplicação na prática, sob o fundamento de constituir incentivo à fraude. $\mathrm{E}$ mesmo na hipótese de ser considerado derrogatório do princípio da indivisibilidade do patrimônio, poderia ser admitido à guisa de mais uma exceção daquele princípio, conforme ocorre em relação ao instituto do abandono liberatório, já existente no âmbito do Direito Comercial Marítimo.

Por último, fizemos ver que, sob qualquer ângulo em que seja encarada, a emprêsa individual de responsabilidade limitada pode e deve ser acolhida no quadro do direito positivo.

Não tivemos a preocupação de traçar os lineamentos basilares do novo instituto, de vez que existem vários projetos de lei preconizando a sua adoção, inclusive um no Brasil, que, aliás, é de autoria de um gaúcho, o deputado Freitas e Castro. Apenas nos limitámos. a solicitar para êle o estudo mais aprofundado e a crítica serena dos. eméritos jurístas que ora se reúnem em Congresso, com o louvável objetivo de, prefencialmente, estabelecer as diretrizes que devem nortear o legislador, na formulação do novo Código de Comércio.

Aí, senhores Congressistas, em síntese, o que procurei expor em minha tese.

Agora, em primeiro lugar, devo reportar-me à objeção levantada pelo professor Hernani Estrella. Agradeço as honrosas referências. que o ilustre catedrático fêz à minha pessoa, e vou procurar definir, ou pelo menos focalizar, da maneira que me parece mais acertada, o conceito de emprêsa; a fim de que fique bem esclarecido o meu ponto. de vista, quanto ao que defendí em minta tese.

Genèricamente considerado, o vocábulo "emprêsa" designa uma atividade plurilateral organizada e dirigida a um determinado fim. Esta poderá ser apreciada sob o aspecto social, econômico e jurídico. Efetivamente, pode a emprêsa refletir uma atividade puramente social e que transcende ao âmbito da economia e do direito, aspecto, aliás, que não nos interessa, pôsto que não pretendemos esboçar uma teoria geral sôbre o assunto.

Encarada do ponto de vista econômico, a emprêsa é uma organização de caráter autônomo que, sob a direção de pessoa singular ou societária, tem por finalidade conjugar os fatôres da produção, com o fito de lucro. Sucinta análise dos vários elementos consubstanciados nessa fórmula, não só demonstrará o fundamento econômico da emprêsa como também poderá fornecer o critério a ser adotado para 0 estabelecimento de uma noção de ordem jurídica.
Em verdade, a idéia de emprêsa nos conduz imediatamente à de organização, isto é, complexo de bens e pluraridade de pessoas, sistemàticamente dispostos e proporcionalmente coordenados, para a obtenção de um fim preestabelecido.

A emprêsa, considerada como organização, possui um caráte autônomo. Esta autonomia resulta da existência de um patrimônio próprio, um domicílio que se não confunde com o do respectivo titular, um objeto ou fim econômico; uso privativo de uma firma ou denominação sob que opera, etc.

É a emprêsa dirigida pelo respectivo empresário, pessoa individual ou coletiva, que nela exerce funções de titularidade e que agirá diretamente ou através do competente órgão de administração.

$\mathrm{Na}$ entrosagem da emprêsa são conjugados os fatôres da produção - natureza, trabalho e capital - de maneira harmônica e racional, a fim de que os processos produtivos possam oferecer o máximo de rendimento com o mínimo de sacrifício.

Por fim, ao mesmo tempo em que a emprêsa se destina a prestar serviços aos elementos externos que com ela se relacionam, também visa para si uma vantagem - o lucro, que, aliás, lhe constitui a característica específica.

Dêsse modo, em resposta à restrição feita pelo professor Hernani Estrella - quanto à confinação da matéria comercial no âmbito das atividades da emprêsa - acredito que o meu pensamento esteja definido, através da explanação ora feita, aliás em consonânciá com o. que se acha exposto em minha tese.

A emprêsa, na acepção restrita de organização, é hoje uma realidade. Nela o comerciante - ou empresário - exerce funções de titularidade, da mesma forma que outros elementos humanos, também indispensáveis à sua entrosagem, exercem igualmente outras tantas funções de titularidade. E' o que se verifica quanto àqueles que, não sendo empresários, formam a categoria dos empregados ou auxiliares da organização. Com efeito, não seria admissível que o proprietário executasse tôdas as tarefas inerentes ao processo produtivo, mesmo porque, se não houver trabalho plurilaterảl, não haverá emprêsa.

De qualquer maneira, porém, tenho a impressão de que se concilia o meu ponto de vista com o professor Hernani Estrella, que é o. da adoção do princípio da limitação da responsabilidade do comerciante individual. Êsse, em última análise, o sentido de minha indicação.

Respondendo ao ilustre professor José Luiz Martins Costa, devo primeiramente, referir-me à esfera própria de atividade jurídica da emprêsa, como resultante da personalidade jurídica. Parece-me que foi êste o primeiro ponto salientado por S. Excia. 
A personalidade, como sabemos, não é qualidade inerente ao homem, do ponto de vista jurídico. Isso, aliás, já foi explicado, de maneira magistral, por Ferrara. Conseqüentemente, o homem é pessoa em virtude do que determina o Direito.

Por outro lado, dois indivíduos se reúnem e põem em comum certa porção de seu patrimônio, para a realização de um negócio comercial determinado. Da consonância de vontade entre ambas as partes resulta o contrato de sociedade, em que reside o substractum da personalidade jurídica da organização.

A emprêsa individual de responsabilidade limitada terá que ter, forçosamente, personalidade jurídica.

O SR. MARTINS COSTA - V. Excia. permite um aparte?

O SR. MARTINS FILHO - Com muito prazer.

O SR. MARTINS COSTA - Quando se trata de sociedade, há vontade coletiva?

O SR. MARTINS FILHO - Êste ponto está anotado aqui e dentre em pouco terei oportunidade de falar sôbre êle.

O SR. MARTINS COSTA - V. Excia. permite? Também a finalidade é coletiva em se tratando de entidade privada da emprêsa, à qual V. Excia. entende que é indispensável a personalidade jurídica? Não sei como se pode verificar êste fato.

O SR. MARTINS FILHO - Da seguinte maneira: quero partir da análise da personalidade jurídica das sociedädes, para chegar a uma conclusão que é favorável a mim e desfavorável a V. Excia.

O SR. MARTINS COSTA - Peço permissão para reler uma passagem de sua tese que, possivelmente, nos auxiliará.

O SR. MARTINS FILHO - Pois não.

O SR. MARTINS COSTA - "Por enquanto limitamo-nos a admitir que é possível o acolhimento da emprêsa individual de responsabilidade limitada, desde que lhe seja reconhecida personalidade jurídica, a igual do que ocorre em relação às sociedades comerciais".

$\mathrm{Eu}$, que vinha encontrando dificuldade, ao ler a sua tese, em aceitá-la, porque achava, tendo em vista o conceito de patrimônio como um atributo da personalidade e atendendo à sua indivisibilidade, ao seu caráter abstrato, à sub-rogação constante que se verifica nos valores que o compõem, eu que vinha, como disse, sentindo dificuldade em aceitar a sua conclusão, sentí-me feliz quando vi que V. Excia. não prescinde dêste elemento essencial, que é a personalidade jurídica. E, como entendo que não é possível haver pessoa jurídica ou entidade moral sem, pelo menos, um fim coletivo, indago de V. Excia. como é que V. Excia. entende que se possa realizar êsse fenômeno.

O SR. MARTINS FILHO - Parece-me que já tive ensêjo de esclarecer bem o meu ponto de vista no que tange à conceituação da emprêsa. Esta, em verdade, só existirá se houver, em seu âmbito, atividade plurilateral, daí resultando o fim coletivo a que alude V. Excia. Assim, na emprêsa de logo se destaca a figura do empresário que, como disse, nela exerce funções de titularidade, já em virtude do capital que constitui o patrimônio da organização, já em conseqüência do trabalho de direção que nela exerce. Destacam-se, também, os demais elementos humanos necessários ao funcionamento da emprêsa e que nela se acham entrosados, como titulares de direitos decorrentes do contrato de locação de trabalho e assegurados pela Legis lação Social Trabalhista. Destarte, parece-me que a minha definição de emprêsa já responderia à objeção levantada por V. Excia.

Examinemos, agora, a questão do patrimônio, com o seu caráter de indivisibilidade, segundo admite V. Excia.

$\mathrm{Na}$ passagem de minha tese relida por V. Excia. apenas afirme que é possível o acolhimento da emprêsa individual de responsabilidade limitada, desde que lhe seja reconhecida personalidade jurídica, a igual do que ocorre quanto às sociedades comerciais.

Certa corrente de doutrinadores admite que a emprêsa individual com limitação dos riscos encontra, na autonomia do seu patrimônio, o substractum da personalidade jurídica, de que necessita. E' a chamada teoria da personalização do patrimônio.

Outra corrente, porém, mais atualizada e com maior soma de fundamentos lógicos, faz derivar aquela personalidade do princípio da autonomia da vontade, manifestada no ato de constutuição da emprêsa. E é exatamente a esta corrente que me associo.

Como será possível conferir personalidade jurídica à emprêsa do comerciante singular, com limitação dos riscos?

Para chegar a uma conclusão satisfatória, pareceu-me aconselhável exemplificar com o tịpo de emprêsa societária. Com efeito, dois ou mais indivíduos - pessoas naturais - reúnem-se com o objetivo comum de explorar uma determinada atividade mercantil. Há, aí, um acôrdo de vontades, consubstanciado no contrato de sociedade, de que emana a personalidade jurídica, uma vez satisfeitas as exigências legais.

Em última análise, vê-se que na constituição da emprêsa coletiva existe apenas uma vontade - a de explorar um negócio ou indústria, sob determinadas condições - sendo que esta vontade é manifestada por dois ou mais agentes.

Pois bem, o mesmo se verifica em relação à emprêsa individual de responsabilidade limitada, isto é, uma vontade expressamente manifestada no ato de constituição, se bem que por um único agente.

Esta teoria - da autonomia da vontade - poderá ser admitida mesmo que se aceite, em tôda a sua rigidez, o princípio tradicional da indivisibilidade do patrimônio. Porque, adquirindo a emprêsa sin- 
gular com limitação dos riscos esfera de atividade jurídca própria, nem por isso deixarão de permanecer vinculados ao patrimônio civil do empresário os direitos, de que é titular, quer quanto aos proventós advindos das operações da emprêsa (o lucro), quer em relação an que resultar de sua liquidação.

Em resumo, do ato de constituição da emprêsa individual ou societária, em que a vontade do respectivo titular (pessoa natural ou sociedade) se acha expressamente manifestada - é que resultará a personalidade jurídica.

Partindo dêsse princípio da autonomia da vontade, acredito que esta teoria será a vencedora.

O SR. MARTINS COSTA - Lamento não poder aceitar essa teoria a que V. Excia se abraça, e que conheço, por ter um caráter, a meu ver, marcadamente materialista. A personalidade moral não pode emanar do patrimônio exclusivamente. Não se pode cindir de u’a maneira absoluta da pessoa criadora. O conceito clássico, e que entre nós ainda prevalece, com relação à personalidade jurídica, é êste que acabo de salientar.

o SR. MARTINS FILHO - Mas não aceita V. Excia. que a personalidade jurídica nada mais é do que uma criação do direito?

O SR. MARTINS COSTA - Não aceito. Aceito que há uma corrente nesse sentido. A personalidade moral não é uma criação, uma fiç̧̃ão. E' uma realidade. O povo brasileiro, a 'Nação brasileira, constituída em Estado, não é uma fiç̧ão, é uma realidade. Há uma coletividade, há interêsses comuns, há tradições comuns, e isso constitui a personalidade moral. Agora, não é criação, não é ficção.

Essa tendência que está se fazendo sentir em diversos recantos. do mundo, de querer transformar os países em verdadeiras emprêsas, e é de observar que a França sofria grandemente essa influência, é fruto de uma doutrina materialista, que procura fazer da personalidade jurídica uma ficção.

V. Excia, me perdoe, mas eu não aceito essa doutrina, aliás sustentada por muitos, de que a personalidade jurídica é uma ficção.

O SR. MARTINS FILHO - A propósito devo ler o que, a êsse respeito, diz Ferrara, em quem, aliás, procurei fundamentar o meu trabalho. V. Excia. deve conhecer, também, essa parte de minha tese.

(Lê) "A personalidade é um produto da ordem jurídica e surge por um reconhecimento do direito positivo".

O SR. MARTINS COSTA - É uma realidade que o direito reconhece.
O SR MARTINS FILHO - ..."O homem é uma pessoa não por natureza e sim por obra do direito. A qualidade natural do homem, como de um ente racional e capaz de vontade, é só a base ética, para que o direito de um certo estadio de cultura reconheça a todos os homens personalidade. Porém a subjetividade não é inata no homem, não é uma qualidade inerente ao indivíduo, senão uma realidade ideal que sem a ordem jurídica é inconcebível”.

O SR. MARTINS COSTA - Nós partimos de escolas diferentes.

O SR. MARTINS FILHO - ..."Em período anterior à organização estatal, o homem não é pessoa”.

O SR. MARTINS COSTA - Isso não quer dizer que não tivesse personalidade anterior a essa ordem materialista.

O SR. MARTINS FILHO - ... "E mesmo constituída a ordem jurídica, a história demonstra que por longo tempo houve uma classe de homens aos quais se negava a qualidade de sujeito de direito - os escravos. E não é só isso: a personalidade também podia ser perdida, por uma condenação penal (morte civil) ou uma adoção do estado religioso (vida claustral). E também nos indivíduos capazes, a personalidade se manifesta como uma quantidade variável, que pode ser reconhecida em mais ou menos larga medida. Històricamente não foram iguais, sob o ponto de vista jurídico, homens e mulheres, cristões e hebreus, nobres e vassalos, sendo que ainda hoje existe diferença entre nacionais e estrangeiros".

O SR. MARTINS COSTA - Então, é questão de capacidade de direito. $\mathrm{O}$ que me parece indispensável é que a emprêsa individual tenha uma personalidade que não se confunda com a do respectivo titular. Aliás, o próprio direito brasileiro adota o princípio quando, em relação ao direito fiscal, estabelece que o comerciante paga impôsto como pessoa de direito...

O SR. MARTINS FILHO - Para efeitos fiscais.

O SR. MARTINS COSTA - Mas, de qualquer forma se trata...

O SR. MARTINS FILHO - Trata-se de uma transformação, que terá também de atingir ao Direito Comercial.

No Direito Trabalhista verificamos o mesmo fenômeno salientado por V. Excia., observamos a mesma tendência em tal sentido. 
De maneira que não seria possível se admitir a emprêsa individual de responsabilidade limitada sem conferir a essa emprêsa personalidade jurídica.

Agora, há outros pontos ainda objetados por V. Excia. Um dêles é quanto à indivisibilidade do patrimônio.

O SR. MARTINS COSTA - Mas, V. Excia. dê licença. Não precisa entrar na apreciação dessa matéria porque se V. Excia. não tivesse sustentado que a emprêsa particular precisa possuir personalidade jurídica, então sim, seria interessante sustentar que o patrimônio não tem essa indivisibilidade que se sustenta que tenha. Mas, uma vez que V. Excia. declarou em seu trabalho considerar indispensável dar personalidade jurídica à emprêsa, isto é questão secundária.

O SR. MARTINS FILHO - A do patrimônio?

O SR. MARTINS COSTA - Sim, porque V. Excia. atribui personalidade. E atribui personalidade para quê? Só para êsse efeito. Se V. Excia. entende que a emprêsa necessita ter personalidade é para êsse efeito, para atribuir patrimônio à emprêsa, porque senão cairíamos numa confusão absoluta. De sorte que êsse se torna um ponto secundário.

O SR. MARTINS FILHO - Mas, não me parece secundário.

O SR. MARTINS COSTA - Digo com relação à matéria, porque V. Excia. deu, dessa premissa, a necessidade de atribuir personalidade jurídica à emprêsa, e para quê? Para atribuir patrimônio ela, porque, do contrário, não lhe podia atribuir. Agora, se V. Excia. sustentasse coisa diversa, isto é, que o patrimônio é divisível, e por isso se deve e pode separar parte dêle para destinar-lhe a outro determinado negócio, seria a meu ver tese mais fácil de sustentar.

O SR. MARTINS FILHO - Abordei a tese sôbre vários aspectos. Esse que V. Excia. versa e também quanto àquele princípio tradicional da indivisibilidade do patrimônio.

Efetivamente, quem se obriga, obriga o que é seu. Mas, essa noção não é absoluta, porque, na esfera jurídica de cada pessoa existe a categoria dos chamados direitos inalienáveis, impenhoráveis, etc. sôbre cujo assunto o professor Bruno Mendonça Lima, diretor da Faculdade de Direito de Pelotas, que aqui se encontra, fêz hoje belíssima preleção, na Comissão de Direito Mercantil e Direito Mercantil Comparado.

Realmente, é tradicional a noção da indivisibilidade do patrimônio. Mas, mesmo assim, procurei enquadrar a minha tese dentro dessa teoria, argumentando e demonstrando que a tese não fere essa apregoada indivisibilidade. Acredito que o comerciante, que criou uma emprêsa individual limitada, não está absolutamente que vidindo o seu patrimônio. Elle apenas separa dêle uma certa porção, à qual dá um fim determinado. E' a chamada afetação de patrimônio, para um fim específico. Mas, ao patrimônio individual permanecem incorporados os direitos que o empresário tem sôbre a emprêsa individual limitada, quanto aos lucros e quanto ao que resultar de sua liquidação. De modo que procurei ferir o assunto em todos os seus aspectos, admitindo também êsse princípio tradicional da indivisibilidade do patrimônio que, aliás, é o mais forte obstáculo que se antepõe à idéia em marcha - e que será vitoriosa - da emprêsa individual de responsabilidade limitada.

O SR. ARMANDO DIAS DE AZEVEDO - Será uma afetação de patrimônio.

O SR. JOSÉ LUIZ MARTINS COSTA - Pode ser afetação de patrimônio para um determinado fim. Quando se fala em patrimônio, evidentemente não se alude aos bens que compõem o patrimônio.

$\mathrm{O}$ SR. MARTINS FILHO - $\mathrm{Na}$ hipótese não se alude à sua totalidade, mas a uma determinada porção do patrimônio.

O SR. MARTINS COSTA - Refiro-me ao patrimônio considerado abstratamente, como continente e não como conteúdo. Evidentemente, qualquer pessoa pode hipotecar, penhorar, pode até separar determinados bens para garantia de certas dívidas, mas o patrimônio é uma universalidade de direito, apanha a totalidade do valor ativo ou passivo, abstratamente considerado. De modo que essa divisão é ụma impossibilidade jurídica.

O SR. MARTINS FILHO - Que significa a emprêsa do tipo societário? V. Excia. e eu, associando-nos, não poderemos organizar uma sociedade de responsabilidade limitada...

O SR. MARTINS COSTA - Mas aí aparece a pessoa jurídica.

O SR. MARTINS FILHO - Aqui, em minha proposição, também aparece.

O SR. MARTINS COSTA - Mas e a personalidade jurídica? Parece-me que há ausência do fim coletivo.

O SR. MARTINS FILHO - O fim coletivo está aqui anotado e vou chegar até êle. O fim coletivo está consubstanciado no interêsse do empresário e também dos demais elementos humanos que são necessários à entrosagem da emprêsa.

O SR. MARTINS COSTA - Mas isto pressupõe já uma finalidade individual. Os elementos humanos que cooperam, cooperam à posteriori.

O SR. MARTINS FILHO - Quem, na indústria ou no comércio, vai cooperar sem a finalidade material? Não é a especulação uma de suas características?

O SR. MARTINS COSTA - Pode-se criar a figura de uma sociedade, se voltarmos à sociedade de capital e indústria, entre os empregados e o patrão. Aí sim. 
O SR. MARTINS FILHO - Mas, sociedade de capital e indústria, de responsabilidade limitada?

O SR. MARTINS COSTA - Para admitir a figura da pessoa jurídica, apenas para êste efeito.

O SR. MARTINS FILHO - Quanto à parte referente à personalidade jurídica e fim coletivo, parece que dei a V. Excia, as explicações que me foram possíveis.

O SR. MARTINS COSTA - São questões de pontos de vista, de escolas diferentes.

O SR. MARTINS FILHO - Na emprêsa individual existe também um interêsse coletivo.

O SR. MARTINS COSTA - Fico muito grato pela exposição de V. Excia.

O SR. MARTINS FILHO - Mas, meus senhores, ainda existe um outro aspecto da questão que eu gostaria de focalizar, porque foi debatido hoje pela manhã na Comissão de Direito...

O SR. PRESIDENTE (comprimindo a campainha) - Devo chamar a atenção do nobre orador, que já esgotou o tempo de que dispunha para falar.

O SR. MARTINS FILHO - Eu agradeço a advertência do sr. Presidente. Realmente, estou me perdendo em considerações que talvez sejam desnecessárias.

Mas acredito, sr. Presidente e senhores Congressistas, que a minha tese é sustentável sob todos os pontos de vista.

Em primeiro lugar, a emprêsa individual de responsabilidade limitada não constitui um incentivo à fraude. Nas operações de ordem econômica deve prevalecer o princípio da boa fé. Se um indivíduo quer efetivamente praticar atos de desonestidade, êsse indivíduo poderá fazê-lo não só por intermédio da emprêsa singular limitada como por meio de um tipo societário qualquer ou ainda, digamos, organizando uma sociedade unipessoal ou fictícia.

Em segundo lugar, a emprêsa individual com limitação dos riscos não é derrogatória do princípio latino tradicional da indivisibilidade do patrimônio, isto porque, como já dsse, ao patrimônio do titular da emprêsa permanecem incorporados os direitos que tem sôbre os proventos resultantes dos negócios e também sôbre o que resultar da liquidação do estabelecimento.

Ademais, a emprêsa individual limitada é uma necessidade no país. Com a sua instituição o legislador regulará, de direito, uma situação que existe de fato, através de sociedades unipessoais e das fictícias, que se alastram por tôda a extensão nacional.

A emprêsa individual de responsabilidade limitada deve ainda existir por um princípio de coerência legislativa, pois que, em matéria de Direito Marítimo já possuímos o instituto do abandono libera- tório, que nada mais é do que a afetação do patrimônio individual, até certo limite, para um fim específico. Poder-se-á dizer que, pela natureza do negócio, é necessário salvaguardar os interêsses de terra em relação aos interêsses de mar. Mas, outras razões encontramos, também fortes e ponderáveis, em favor da adoção da emprêsa singular limitada, entre elas a necessidade indeclinável de incrementar os negócios, facilitando a movimentação de capitais que permanecem estáticos, como brilhantemente o demonstrou o professor Júlio César Bonazzola.

Por tudo isso, sr. Presidente, estou na convicção de que, dentre em breve, a emprêsa individual de responsabilidade limitada será um novo instituto admitido pelo nosso legislador e que irá completar, satisfatòriamente, o sistema do Direito Comercial Brasileiro. (Palmas).

O SR. PRESIDENTE - Concedo a palavra ao dr. Paulo Barbosa Lessa, relator do parecer.

O SR. PAULO BARBOSA LESSA - Exmo. Sr. Waldemar Ferreira, Presidente dêste Congresso, exmos, srs. membros da Mesa, snrs. congressistas, minhas senhoras e meus senhores. Quero, inicialmente, salientar a honra de ter sido o relator desta tese na Comissão de Direito Mercantil e Direito Mercantil Comparado.

Para infelicidade do sr. professor Antonio Martins Filho, o relator de sua magnífica tese foi excessivamente pobre (não apoiados). Cabe-me, pois, fazer um relatório iniciàl, a fim de pôr o problema em tela de discussão.

Seria, talvez, necessário fazer um intróito a êste relatório, pois que os srs. Congressistas não dispõem, na sua totalidade, do texto da tese em referência. No entanto, depois do debate brilhantemente travado, êste trabalho parece-me não precisa ser feito. De maneira que vou ler o relatório que foi apresentado à Comissão, a fim de que esta entrasse no mérito da discussão da tese. $(L \hat{e})$ :

" 1 - Analisa o autor da tese um dos mais importantes e sedutores problemas do novo direito mercantil. Pode dizer-se que o Prof. da Faculdade do Ceará toca no âmago da questão mais apremiante para as consciências dos comercialistas contemporâneos: a tese da caracterização da matéria mercantil pela emprêsa, a tese de que o direito comercial é um direito das emprêsas.

Tem, indiscutìvelmente, a tese do Professor cearense o inegável mérito de trazer à barra da discussão problema de tão vivo interêsse, teórico e prático. É, talvez, a mais completa confissão de adesão à nova teoria comercialística feita por professor brasileiro. Isso importa, quando menos, em tornar inadiável à doutrina brasileira a discussão do assunto. Talvez essa monografia marque o ponto de partida de uma ampla discussão do tema, discussão oportuna em momento em que se cuida da reforma da legislação comercial pátria.

$22-$ R. D. $1 .^{\circ}$ Vol. 
2 - Não se ignorá a profunda repercussão da tese de que o diretto mercantil é um direito de emprêsa na doutrina e na legislação as mais modernas. O exemplo do Código rumeno, e, notadamente, a modêlo trazido pelo recente Código civil italiano, tem ensejado amplas controvérsias sôbre o tema.

Deve, contudo, ser ressaltado que na própria Itália, onde, mercê da reforma legislativa, se apóia o direito mercantil no conceito de emprêsa, é a noção de emprêsa perigosamente vacilante. Não existe, em absoluto, um conceito de emprêsa sòlidamente implantado na doutrina. Não há, sequer, concordância entre os mestres sôbre os elementos essenciais do conceito. As discordâncias atingem o âmago da noção. Porisso mesmo, afirma-se e nega-se, na Itália, ser o novo. direito comercial um direito de emprêsa. E é oportuno ressaltar a opinião de Alberto Asquini, que vê, face à lei vigorante, quatro significados da palavra emprêsa: um significado subjetivo, um significado objetivo, um significado funcional e um último significado institucional ou corporativista.

3 - Deve dizer-se, ainda, que, apesar de já antes existir projeto baseado no conceito de emprêsa - o de Asquini, em 1939 -, a novo Código não surgiu de um assentimento generalizado da doutrina, mas sofreu, iniludivelmente, dos processos autoritários na sua sistematização, já de um ângulo econômico-social, já mesmo de um ponto de vista político".

\section{(Interrompendo a leitura)}

Aqui, coube ao jubilado professor Waldemar Ferreira a oportunidade de trazer o depoimento pessoal, colhido do mestre italiano, quando relatou que, já estando prontos os três livros primeiros do novo Código Italiano, o Ministro Dino Grandi solicitou ao professor Asquini, que, de certo modo, enxertasse aquela sua obra bastante caracterizada naquele todo único. $\mathrm{O}$ professor ponderou que aquêles três primeiros códigos repousavam em concepções diversas da quesustentava no sistema que havia engendrado e o Ministro Dino Grandi propôs, de certa forma fêz uma exigência, dizendo que havia necessidade de que o Código fôsse assim, porque o Poder Executivo assim o desejava. E, ainda mais, que estava até marcada a data para a promulgação do novo Código. E foi dêsse modo, que o professor Asquini procurou torcer a sua concepção, a fim de adaptá-la ao todo geral. Mas, não houve tempo para que êste Código fôsse assim promulgado, de tal sorte que, no dia da promulgação, a lei, enfeixada num volume, foi, na realidade, promulgada em branco e só posteriormente é que, efetivamente, os seus artigos foram redigidos.
De maneira que, de certa maneira, temos a confirmação do que salientava o Relatório...

\section{(Prosseguindo a leitura):}

“A doutrina mais autorizada tem concluído, além do mais, pela autonomia do direito comercial no novo sistema italiano, apesar da concentração de normas em código único. Como figura central dessa nova matéria surge o conceito de "emprêsa sujeita a registro". Mas, pràticamente, o enquadramento do problema ainda repousa num critério objetivo, dado pela realidade da atividade desenvolvida organizadamente. Donde, revive, em derradeiro, o critério objetivo para separar as duas matérias: a civil e a comercial.

4 - Em nosso país, a questão tem passado um tanto despercebida. Necessário é que, em tôrno dela, se proceda percuciente discussão. A prudência aconselha, contudo, que se não tome precipitadamente posição definitiva sôbre a adequação ou não do novo conceito ao novo Código de comércio. Repousar a nova construção sôbre o conceito único de emprêsa, como pretende o autor, com o abandono total da noção tradicional de ato de comércio, é tese que comporta uma bem ampla pesquisa, antes de veridito definitivo. Mesmo porque há quem sustente o apêlo às duas noções, que se não excluiriam portanto, antes se completariam, para u'a mais perfeita adequação do problema legislativo.

5 - Aliás, êsse apêlo de prudência não tolhe o exame da tese fundamental cristalizada na monografia: a de que é conveniente ao sistema mercantil pátrio a inclusão da figura da emprêsa individual de responsabilidade limitada. Isso porque as duas teses se não confundem. Não é preciso sustentar-se ambas. Afirme-se a de que o direito mercantil é direito de emprêsa, e se não conclua pela limitação da responsabilidade individual, como faz o texto legislativo italiano, no sentir de muitos. Ou negue-se a caracterização da matéria mercantil pela emprêsa, e sustente-se a validade da limitação de responsabilidade, como faz Arecha, citado pelo autor. E, em ambos os casos, contradição inexiste.

6 - Em realidade, existem na tese do comercialista cearense dois pontos a abordar: um de técnica jurídica, outro de conveniência econômica.

O primeiro responde à pergunta: é possível figurar jurìdicamente a limitação da responsabilidade do comerciante? $O$ segundo assim se formula: é conveniente, para o comércio, a limitação da responsabilidade do comerciante individual? Aquêle é um problema jurídico. Este um problema político-econômico.

7 - Parece não existir, do ponto de vista jurídico, impedimento de 
ordem técnica para que se configure em lei a limitação da responsabilidade do comerciante individual. Sem se cair nas doutrinas extremadas do patrimônio de afetação ou da personificação do estabelecimento, pode a ordem jurídica solucionar afirmativamente a questão. Conceituada a personalidade jurídica como uma relação, cabe à ordem jurídica, sancionando os anseios da vontade privada, plasmar pessoa jurídica, dando-lhe contornos próprios.

Por outro lado, o problema da necessidade do consêrto de pelo menos duas vontades para plasmar sociedade ao caso não colhe, pois de sociedade não se trata. À simples vontade individual, como no caso de fundação, dá a ordem jurídica o poder de trazer à existência jurídica a nova pessoa.

Nem é a noção de unidade do patrimônio óbice decisivo. A noção de patrimônio não é, de feito, essencial à pessoa. De resto, limitações patrimoniais se conhecem. A tese traz apenas mais outra exceção ao princípio geral.

8 - Quanto à oportunidade econômica do novo instituto, não cabe, primacialmente, aos juristas resolver. Aceite-se a constatação de que, em realidade, se tem procurado, à sombra das instituições vigentes, chegar, por via indireta, ao resultado que a nova figura procura, diretamente, atingir. E' fato de todos os dias, de verificação facílima, e impossível de ser negado. Convenha-se que o sistema jurídico pode, através de regulamentação adequada, conter o fenômeno da fraude que, aliás, se manifesta em todos os campos do direito. Além disso, penetrá-se em campo desbordante da matéria jurídica.

Êsse o nosso parecer, s. m. j..

\section{PARECER}

“A Comissão de Direito Mercantil e Direito Mercantil Comparado:

- aceita, em princípio, as conclusões das teses apresentadas pelos professôres Drs. MARTINS FILHO e SALVADOR PERROTTA, sôbre A EMPRESA INDIVIDUAL DE RESPONSABILI$D A D E$ LIMITADA -; mas recomenda que o assunto seja estudado de molde a assegurar convenientemente os direitos de terceiros.

E assim decidiu por maioria de votos, contra o voto do Professor WALDEMAR FERREIRA, que vai em seguida declarado. Pôrto Alegre, 12 de agôsto de 1950.

a) Waldemar Ferreira

a) J. C. Bonazzola (a) HERNANI ESTRELLA, fazendo abstração de qualquer referência ao vocábulo "emprêsa", por preferir que se diga "responsabilidade do comerciante singular ou individual".

Louvo os trabalhos dos Professôres MARTINS FILHO e SALVADOR PERROTTA sôbre a emprêsa individual de responsabilidade limitada; mas divirjo de sua conclusão, parecendo-me que a lei não deve sufragar tal instituto, antes tomar medidas que tutelem o crédito. Nem compreendo que se limite a responsabilidade do comerciante, sem que também se limite a sua possibilidade de contrair dívidas. E, de outro lado, também não compreendo que se outorgue ao comerciante vantagem de que não gozam os não comerciantes que exercitam atividades econômicas de maiores riscos, romo, por exemplo, as agrícolas. - Pôrto Alegre, 12 de agôsto de 1950.

\section{(a) WALDEMAR FERREIRA"}

O parecer não foi, na realidade, aceito pela egrégia comissão, em todos os seus pontos, de tal sorte, que depois de ter sido abordado o problema durante cêrca de uma hora e meia, a Comissão deliberou, por maioria, apresentar ao plenário dêste Congresso a seguinte proposição: (Lendo):

\section{"INDICAÇÃO}

Aceitar, em princípio, o regime de responsabilidade limitada da emprêsa individual, com a recomendação ou reserva de estudar o regime ou instrumento de garantia de terceiros.

Pôrto Alegre, 12 de agôsto de 1950.

(ass.) JÚLIO CÉSAR BONAZZOLA, PAULO BARBOSA LESSA, A. MARTINS FILHO, VICENTE MAROUES SANTIAGO, BRUNO M. LIMA, HOMERO MARTINS BAPTISTA, NEY WIEDMANN, HENRIQUE RUPP JUNIOR.

Aceito e louvo o esplêndido trabalho do Prof. Martins Filho com premissa de alto valor para prosseguimento do estudo e ulterior decisão. (A) HERNANI ESTRELLA. - ” 
O SR. WALDEMAR FERREIRA - Vamos proceder à votação. Para facilidade do trabalho vou tomar, primeiro, os votos dos que votam a favor, e depois dos que votam contra.

Os Congressistas inscritos que aprovam as conclusões tenham a gentileza de se levantarem.

Está aprovada a conclusão do relatório relativamente à primeira proposição.

Vou submeter a votos as outras duas conclusões do relatório do professor Hernani Estrella, relativamente à proposta do professor Perrotta. Uma é no sentido de que a questão relativa ao crédito bancário confirmado o Congresso recomende seja estudada por um Congresso Internacional, prefentemente latino-americano, que examinará, então, as possibilidades de sua adoção pelas leis dos diversos países. Os que aprovam esta conclusão queiram se conservar sentados. (Pausa) Aprovado.

A terceira conclusão é a seguinte que, "diante da proposta no sentido de que o Congresso recomende a adoção dos votos múltiplos nas ações das sociedades anônimas, o parecer é contrário a esta proposição, pela razão de que existe lei no Brasil contrária também a esta mesma proposição, e está de acôrdo com a doutrina mercantil brasileira.

Os que votam pela conclusão, queiram ficar sentados. (Pausa).

Está aprovado o parecer.

Estamos com a nossa hora adiantada. Quero, em primeiro lugar, agradecer aos prezados colegas e aos Congressistas o seu comparecimento a esta sessão. Em segundo lugar, quero felicitar aos que debateram as teses que se apresentaram e também aos que as debateram nas comissões. Isto nos demonstra que é muito vivo e por isso mesmo muito cintilante o espírito jurídico dos meus prezados amigos e patrícios do Rio Grande do Sul.

Faço votos que continuem os nossos trabalhos com êste mesmo brilho, porque isto será um bem e um prazer, afinal de contas, para nós. Está encerrada a sessão.

\section{COMUNICACION AL CONGRESSO JURIDICO CONMEMORATIVO DEL CINCUENTENARIO DE LA FACULTAD DE DERECHO DE RIO GRANDE DEL, SUD - (Brasil)}

\author{
SOBRE: ACTOS DE COMERCIO.
}

\section{Waldemar Arecha} Profesor Adjunto de Derecho Comercial en la Facultad
de Derecho de Buenos Aires. Profesor Adjunto de Sociedades Anónimas y Seguros en la Facutad de Ciencias Económicas de Buenos Aires.

Las tentativas de reformar el Código de Comercio en cualquier país no deben perder de vista un punto de partida primario $\mathrm{y}$ necesario para que la reforma resulte provechosa y ordenada.

Entiendo que todos los afanes y esfuerzos que se presten para la reforma y perfeccionamiento de las múltiples instituciones del derecho mercantil, no serán bastantes si no se cuida de que los principios básicos o rectores que determinen la importancia y el ámbito mercantil estén perfectamente ordenados y expuestos en el curepo orgánico de leyes (Código) que se pretende reformar.

Es pues evidente, que el mayor cuidado de la reforma debe estar - para que el cimiento sea sólido - en lo atinente al acto de comercio. $\mathrm{Y}$ que no se debe eludir de tratar esta cuestión en virtud de las dificultades que élla ofrezca.

Si toda la autonomía del derecho mercantil, o por mejor decir, su propia existencia radica - valga la paradoja - en la afirmación consciente de que existe la materia mercantil, es indudable y fundamental que élla debe ser enunciada y no dársela por supuesta. Esto último comporta dejar abiertas las puertas para que se presenten ulteriores confusiones del ámbito civil y del derecho mercantil, y para que toda la arquitectura de la reforma pueda sentirse invadida de elementos extraños, o pueda a su vez invadir otros ámbitos que no sean los propios.

Para abordar la tarea de enunciar el ámbito mercantil es necesario olvidar los clássicos puntos enunciativos o enumerativos del Código de Napoleón y de los que lo subsiguieron, lo mismo que la 